\title{
Study on Irrigation Water Quality in the Rift Valley Areas of Awash River Basin, Ethiopia
}

\author{
Zeyede Aregahegn (iD) ${ }^{1}$ and Mulate Zerihun ${ }^{2}{ }^{2}$ \\ ${ }^{1}$ Natural Resource Management Research Department, Melkasa Agricultural Research Center, EIAR, P.O. Box 2003, \\ Addis Ababa, Ethiopia \\ ${ }^{2}$ Food Science and Nutrition Research Department, Melkasa Agricultural Research Center, EIAR, P.O. Box 2003, Addis Ababa, \\ Ethiopia \\ Correspondence should be addressed to Zeyede Aregahegn; zeyede.aregahegn@eiar.gov.et
}

Received 17 August 2020; Revised 24 December 2020; Accepted 19 January 2021; Published 8 February 2021

Academic Editor: Fedor Lisetskii

Copyright ( 2021 Zeyede Aregahegn and Mulate Zerihun. This is an open access article distributed under the Creative Commons Attribution License, which permits unrestricted use, distribution, and reproduction in any medium, provided the original work is properly cited.

\begin{abstract}
Awash River water has been impaired by various types of pollution owing to waste released from different socioeconomic activities in its basin. This study aimed to evaluate the water quality of the Awash River and its tributaries in the basin used for irrigation purposes. Sampling sites were identified based on the pollution sources, accessibility, and land-use coverage. A total of 17 sampling sites were chosen along the Awash River, and samplings were collected four times a year through different seasons. The overall water quality and suitability for irrigation are explained using multiple water quality parameters such as $\mathrm{pH}, \mathrm{EC}, \mathrm{SAR}, \mathrm{RSC}$, $\mathrm{Na}^{+}, \mathrm{K}^{+}, \mathrm{Ca}+\mathrm{Mg}, \mathrm{CO}_{3}{ }^{2-}, \mathrm{HCO}_{3}{ }^{-}$, and $\mathrm{Cl}^{-}$. The obtained results showed that all quality parameters at Beseka Lake exceed the maximum permissible limit of suitability for irrigation. It is generally conceivable that the physicochemical characteristic of the Awash River varies in different water quality parameters at different sites. Only Beseka Lake and Meteka hot spring water exceeded $\mathrm{pH}$ and SAR permissible limit, and EC at Mojo, Wonji, Beseka, Melkasedi, Werer, Ambash, Meteka, and Meteka hot spring shows medium-to-high salinity scale, while RSC was very high at Beseka, Melkasedi, Meteka hot spring, Ambash, Meteka Mojo, Werer, Assayta, Wonji, Dupty, Tibila, Metehara, and Afambo, respectively. The establishment of wastewater treatment plants for industries and stormwater quality management at hotspot areas are recommended to improve the water quality, and dispatch proportion needs to be considered in the future.
\end{abstract}

\section{Introduction}

Irrigation plays an important role in agriculture for the development of a country's economy since ancient civilizations. However, irrigation also becomes damage for farmlands unless the proper management is practiced timely. In Ethiopia, irrigation activities for small- and largescale farmlands were practiced for a long time, especially in the Rift Valley of Awash River Basin. Awash River water plays an important role in the socioeconomic and ecological activities [1] of pastoral and agropastorals in the basin. The basin faces water shortage for irrigation and household activities during the dry season and faces flooding during the rainy season [2]. The basin covers a catchment area of $110,000 \mathrm{~km}^{2}$ with a length of $1200 \mathrm{~km}$ and serves as home to
18.6 million inhabitants [2-4] from a high plateau near Ginchi town, about $80 \mathrm{~km}$ to the west of Addis Ababa, and flows along the rift valley into the Afar triangle and ends in saline Lake Abbe [5]. Awash River, rising near Addis Ababa and flowing $800 \mathrm{~km}$ to a swampy lake near the Djibouti border (Figure 1), is the main basin for agricultural and industrial activities. It is the major component of the Ethiopian economy which is used as a water supply source for households, hydropower, national park, industries, and small- to large-scale irrigation schemes of sugarcane, cotton, fruit, vegetable, and flower farms $[2,6]$. Awash River Basin is one of the largest, most developed, and most utilized river basin in Ethiopia [2, 4, 7] with a number of small-, medium-, and large-scale irrigation schemes, industries located along the river; wide rural inhabitants, and fast urban development 


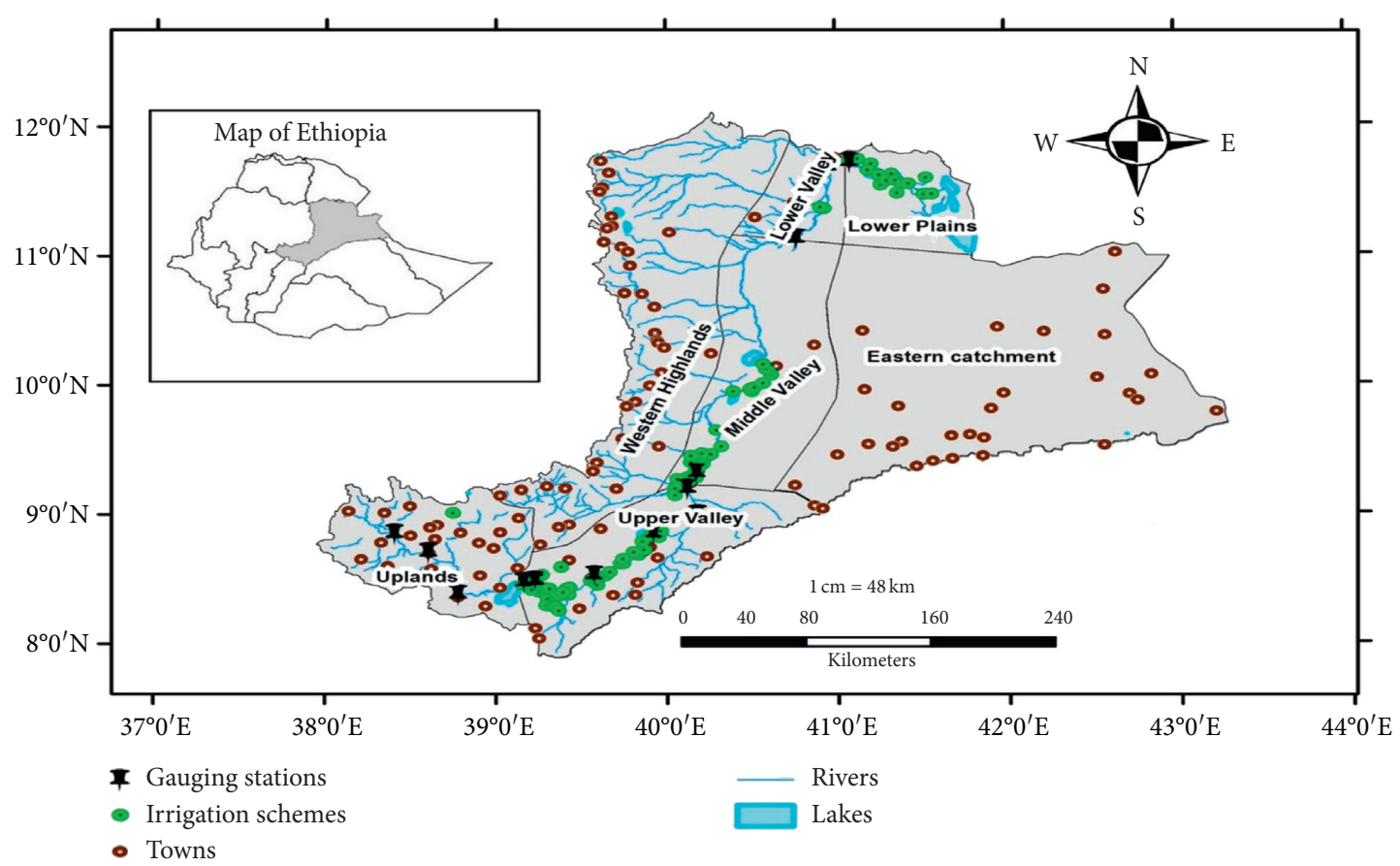

Figure 1: Map showing routes of the Awash River.

that require a substantial amount of water supply schemes. Large sugar estates and processing of horticultural crops, fruits, and vegetables in the upper, middle, and lower Awash valley which plays a considerable positive contribution to the growth and economic development of the nation as a whole use Awash River water [8]. Most of the irrigation activities in these areas are traditional, and some government-owned and other private investments in irrigated agriculture use modern irrigation systems including sprinkler and drip irrigation. In addition to these key economic sectors, various activities were taking place such as textiles, slaughterhouses, tanning, leather products, and others located in this basin [9].

The basin's mean annual precipitation is $560 \mathrm{~mm} /$ year and has yearly evapotranspiration of $503 \mathrm{~mm} /$ year [2]. The basin's mean annual rainfall ranges from 100 to $1700 \mathrm{~mm}$ and also has a potential of 8.2 BCM and 10.3 BCM surface and groundwater, respectively, with $300 \mathrm{~m}$ exploration $[7,10]$. The total mean annual water resources of the Awash River Basin amounts to $4900 \mathrm{~mm}^{3}$ of which $3850 \mathrm{~mm}^{3}$ is currently utilized [11].

The Awash River Basin is divided into upper, middle, and lower Awash River Basin areas. In the upper Awash River Basin area, industrial, hydroelectric, and agricultural practices are the most dominant economical activities. Large and small industries near Addis Ababa, Mojo and Adama, Wonji, and Metehara sugar factory are among the industrial activities alongside the Awash River of the upper basin, while Kesem Kebena and Tendaho sugar factory are the two major industrial activities found in the middle and lower Awash River Basin areas, respectively. Koka hydroelectric power station in the upper part of the basin is also one of the oldest hydroelectric power stations in the country for which the hydroelectric dam was built on Awash River. Different small- and large-scale irrigation farms including upper
Awash agroindustry and Metehara sugar farms are among the agricultural activities in the upper basin. Melkasedi and Ambash irrigation schemes and Werer Agricultural Research Center station are the largest and major agricultural practices in the middle Awash River Basin. In the lower Awash River Basin, small-scale irrigation farms were in practice but most of the area was arable. However, recently large-scale wheat production was expanded in the area at which the Ethiopian Government targets these areas for the production of wheat to replace imported wheat by local production.

However, Awash River water has been impaired by various types of pollution owing to waste released from different socioeconomic activities [12] and poor agricultural activities and irrigation management in the basin. The dominant water pollution in Awash River Basin comes from excess pumping and overflowing during irrigation, discharge of saline Beseka Lake water and hot spring water from different sites to the river, urbanization, and industrial waste. The need for industrialization approaches for the development of the country's economy currently increased. However, in Ethiopia, most of the industries were built alongside the rivers to discharge their wastewater easily into the river and nearby water bodies and open spaces in which some of the industries have a treatment plant and some of the industries released wastewater without prior treatment. Around $65 \%$ of industries in Ethiopia including the two main industrial zones of the country (Dire Dawa and Kombolcha), national industrial hotspots and corridors, agroindustries, and highly populated cities and towns in the country are found inside the Awash River Basin [2]. The sources of pollution on Awash River are the production of industrial and rural waste residual discharge in urban and industrial areas of Akaki, Mojo, and Wonji [9]. 
The classification of the water quality based on the degree of purity and pollution dates to 1848, in Germany; then, over the years, several water quality parameters and environmental indicators have been developed based on physicochemical and microbiological characteristics [13]. For irrigation water, the concentration of soluble salts (cations and anions) is used to determine the quality of irrigation water and helps to evaluate the suitability of the water for irrigation purposes. The criteria for the quality of irrigation water are classified as water salinity (EC), sodium adsorption ratio or sodium hazard (SAR), residual sodium carbonate (RSC), sodium percentage $(\% \mathrm{Na})$, soluble sodium percentage (SSP), kelley's ratio (KR), and total hardness [14]. SAR is the relative proportion of sodium $\left(\mathrm{Na}^{+}\right)$to calcium $\left(\mathrm{Ca}^{2+}\right)$ and magnesium $\left(\mathrm{Mg}^{2+}\right)$ ions; RSC is the concentration of bicarbonate $\left(\mathrm{HCO}_{3}{ }^{-}\right)$and carbonate $\left(\mathrm{CO}_{3}{ }^{2-}\right)$ anions as it relates to $\mathrm{Ca}^{2+}$ and $\mathrm{Mg}^{2+}$ ions [15]. SSP is the relative proportion of $\mathrm{Na}^{+}$and $\mathrm{K}^{+}$to total major cations $\left(\mathrm{Ca}^{2+}, \mathrm{Mg}^{2+}, \mathrm{K}^{+}\right.$, and $\left.\mathrm{Na}^{+}\right), \% \mathrm{Na}$ is the relative proportion of $\mathrm{Na}^{+}$to the other four major cations $\left(\mathrm{Ca}^{2+}, \mathrm{Mg}^{2+}, \mathrm{K}^{+}\right.$, and $\mathrm{Na}^{+}$), and $\mathrm{KR}$ is the relative proportion of $\mathrm{Na}^{+}$to that of $\mathrm{Ca}^{2+}$ and $\mathrm{Mg}^{2+}$ (Kadyampakeni et al., 2018).

The development of different activities such as agriculture, industry, and urbanization, especially around the Awash River, has a significant effect on the quality of water. Nowadays, the expansion of Beseka Lake becomes a challenge for Awash River water quality, especially to the downstream area of the basin affected because the lake contains a significant amount of salt. Expansion of industries around the cities of Akaki, Mojo, and Adama has its own impact on the pollution of Awash River water. The quality of natural water sources used for different purposes should be established in terms of the specific water quality parameters that mostly affect the possible use of water for irrigation.

Awash River has different tributaries such as other rivers from different sites, streams, springs, and hot springs in which each of the tributaries plays an important role in the quality of Awash River water. In the Awash River Basin, the lives and activities of pastoral and agropastoral communities are highly dependent on this river. Due to the repeated and poor irrigation practices and the increasing amount of Beseka Lake water flow to the downstream area, soil salinity becomes a challenge especially in the middle and lower Awash River Basin areas. Salinization of large- and smallscale irrigation farms increased from time to time in these areas.

Soil salinity is a measure of the concentration of total soluble salts in the soil to water solution and is usually expressed as electrical conductivity (EC), sodium absorption ratio (SAR), soluble cations such as sodium $\left(\mathrm{Na}^{+}\right)$, calcium $\left(\mathrm{Ca}^{2+}\right)$, magnesium $\left(\mathrm{Mg}^{2+}\right)$, and potassium $\left(\mathrm{K}^{+}\right)$, and the anions such as chloride $\left(\mathrm{Cl}^{-}\right)$, bicarbonate $\left(\mathrm{HCO}_{3}{ }^{-}\right)$, and carbonate $\left(\mathrm{CO}_{3}{ }^{2-}\right)$ [16]. There are a limited number of studies that focused on Awash River water quality in the basin. The limitation of these studies in the basin is that they focused on only specific places and did not cover the whole basin and many of the studies focused on geological and biodiversity. Since Awash River water has a significant impact on the country's economic and ecological activities, more studies have to be done to know the status and future impact of the irrigation water quality in the basin. In this study, a systematic approach has been carried out to explore the physicochemical characteristics of Awash River water in seventeen different sites of the rift valley areas of Awash River Basin in Ethiopia. The study covers a very large area of the basin (nearly $665 \mathrm{~km}$ ) which starts from the upper Awash River Akaki near Addis Ababa and ends at Afambo in the lower Awash River.

\section{Materials and Methods}

2.1. Sampling Sites. Sampling sites were selected from the upper, middle, and lower Awash River Basin areas (located from Akaki $08^{\circ} 87^{\prime} 65.9^{\prime \prime} \mathrm{N}$ and $38^{\circ} 78^{\prime} 48.5^{\prime \prime}$ in E to Afambo $11^{\circ} 51^{\prime} 50.4^{\prime \prime} \mathrm{N}$ and $\left.41^{\circ} 56^{\prime} 74.8^{\prime \prime} \mathrm{E}\right)$. The sampling site starts from upper Awash (Akaki which is near Addis Ababa) and ends at Afambo (which is near to the Djibouti border). The river with the sampling points is $665 \mathrm{~km}$ long and contains different tributaries, springs, and ponds. For this study, the sampling sites for Awash River water quality include Akaki, Mojo, Koka, Wonji, and Melkasa, which were among the upper part of the basin, Tibila, Metehara, Beseka, Melkasedi, Werer, and Ambash which were among the middle part of the basin, and Meteka, Meteka hot spring, Ada' etu, Mille, dupty, Assayta, and Afambo which were among the lower part of the river. Among the significant river contamination sources, wastewater from industries at Akaki, Mojo, and Adama, overflow of Beseka Lake, and large-scale irrigation schemes at upper, middle, and lower Awash River Basin were the major sampling areas. These sampling sites were selected such that both could provide access to the river and offer representative samples of water quality along the river length. For this purpose, a total of seventeen sampling sites were selected. The locations of different sampling sites are given in Table 1.

$\mathrm{pH}_{\mathrm{w}}, \mathrm{EC}$, carbonate, and bicarbonate alkalinity $\left(\mathrm{CO}_{3}{ }^{2-}\right.$, $\left.\mathrm{HCO}_{3}{ }^{-}\right)$, soluble chloride ion $\left(\mathrm{Cl}^{-}\right)$, soluble sodium, and potassium ion $\left(\mathrm{Na}^{+}\right.$and $\left.\mathrm{K}^{+}\right)$were determined by employing standard determination methods of the International Center for Agricultural Research in the Dry Area (ICARDA) [17]. Sampling seasons, months in each season, sampling month, and flowing characteristics are described in Table 2.

2.2. Water Sampling and Analysis. The sampling procedure of the irrigation water sample for the analysis of the physicochemical parameters was carried out at the selected Awash River sampling sites using the collection vessel immersion technique at a minimum depth of $30 \mathrm{~cm}$ from the water column [18]. Polyethylene flasks with a capacity of $1 \mathrm{~L}$ were used for the collection of samples. Samples were collected four times per year, in which each sampling season was selected based on the flow rate of different seasons. The samples were collected and transported to Werer Agricultural Research Center, Soil and Water Analytical Laboratory, and refrigerated $\left( \pm 4^{\circ} \mathrm{C}\right)$ in a refrigerator shortly after sample collection, and the required physicochemical parameters were analyzed following the standard procedure of irrigation water quality analysis. 
TABLE 1: Locations for sampling sites of the Awash River.

\begin{tabular}{lccc}
\hline Location name & Altitude $(\mathrm{m})$ & Northing & Easting \\
\hline Akaki & 2058 & $08^{\circ} 87^{\prime} 65.9^{\prime \prime}$ & $38^{\circ} 78^{\prime} 48.5^{\prime \prime}$ \\
Mojo & 1738 & $08^{\circ} 59^{\prime} 41.6^{\prime \prime}$ & $39^{\circ} 10^{\prime} 91.8^{\prime \prime}$ \\
Koka & 1591 & $08^{\circ} 40^{\prime} 66.8^{\prime \prime}$ & $39^{\circ} 02^{\prime} 05.0^{\prime \prime}$ \\
Wonji & 1550 & $08^{\circ} 45^{\prime} 57.0^{\prime \prime}$ & $39^{\circ} 23^{\prime} 09.8^{\prime \prime}$ \\
Melkassa & 1539 & $08^{\circ} 40^{\prime} 25.0^{\prime \prime}$ & $39^{\circ} 32^{\prime} 91.7^{\prime \prime}$ \\
Tibila & 1237 & $08^{\circ} 50^{\prime} 88.0^{\prime \prime}$ & $39^{\circ} 56^{\prime} 48.0^{\prime \prime}$ \\
Metehara & 980 & $08^{\circ} 76^{\prime} 24.8^{\prime \prime}$ & $39^{\circ} 88^{\prime} 52.0^{\prime \prime}$ \\
Beseka & 955 & $08^{\circ} 88^{\prime} 69.2^{\prime \prime}$ & $39^{\circ} 091^{\prime} 77.6^{\prime \prime}$ \\
Melkasedi & 747 & $09^{\circ} 20^{\prime} 54.0^{\prime \prime}$ & $40^{\circ} 11^{\prime} 85.4^{\prime \prime}$ \\
Werer & 739 & $09^{\circ} 33^{\prime} 44.8^{\prime \prime}$ & $40^{\circ} 17^{\prime} 13.6^{\prime \prime}$ \\
Ambash & 726 & $09^{\circ} 45^{\prime} 29.7^{\prime \prime}$ & $40^{\circ} 23^{\prime} 52.2^{\prime \prime}$ \\
Meteka & 576 & $09^{\circ} 97^{\prime} 47.9^{\prime \prime}$ & $40^{\circ} 51^{\prime} 84.9^{\prime \prime}$ \\
Meteka hot spring & 572 & $09^{\circ} 97^{\prime} 76.7^{\prime \prime}$ & $40^{\circ} 54^{\prime} 11.6^{\prime \prime}$ \\
Mille & 490 & $11^{\circ} 41^{\prime} 27.7^{\prime \prime}$ & $40^{\circ} 75^{\prime} 97.8^{\prime \prime}$ \\
Dupty & 376 & $11^{\circ} 72^{\prime} 57.1^{\prime \prime}$ & $41^{\circ} 08^{\prime} 58.1^{\prime \prime}$ \\
Assayta & 358 & $11^{\circ} 54^{\prime} 37.6^{\prime \prime}$ & $41^{\circ} 44^{\prime} 97.5^{\prime \prime}$ \\
Afambo & 351 & $11^{\circ} 51^{\prime} 50.4^{\prime \prime}$ & $41^{\circ} 56^{\prime} 74.8^{\prime \prime}$ \\
\hline
\end{tabular}

2.3. Analytical Methods. The chemical constituents of the water samples were analyzed following the standard methods of soil, plant, and water analysis [17]. $\mathrm{pH}$ and electrical conductivity (EC) were measured directly using benchtop $\mathrm{pH}$ and EC meter, respectively, which were calibrated before taking readings. The total alkalinity as carbonate $\left(\mathrm{CO}_{3}{ }^{2-}\right)$ and bicarbonate $\left(\mathrm{HCO}_{3}{ }^{-}\right)$was measured by the volumetric titrimetric method. Soluble calcium $\left(\mathrm{Ca}^{2+}\right)$ and magnesium $\left(\mathrm{Mg}^{2+}\right)$ ions were measured by the ethylene di-amine tetra acetic acid (EDTA) titration method. Watersoluble chloride $\left(\mathrm{Cl}^{-}\right)$was measured by titration with the silver nitrate $\left(\mathrm{AgNO}_{3}\right)$ method. The chemical constituent of potassium $(\mathrm{K})$ and sodium $(\mathrm{Na})$ was measured by the flame emission photometry method. Sodium adsorption ratio (SAR), soluble sodium percentage (SSP), sodium percentage $(\% \mathrm{Na})$, Kelley's ratio (KR), and permeability index (PI) were calculated from the measured values of $\mathrm{Na}, \mathrm{K}, \mathrm{Ca}$, and $\mathrm{Mg}$ 2018) [19], and residual sodium carbonate (RSC) was calculated from the measured values of $\mathrm{HCO}_{3}{ }^{-}$and $\mathrm{CO}_{3}{ }^{2-}$ relative to $\mathrm{Ca}$ and $\mathrm{Mg}$.

$$
\begin{aligned}
\mathrm{SAR} & =\frac{\mathrm{Na}^{+}}{\sqrt{\mathrm{Ca}^{2+}+\mathrm{Mg}^{2+}}}, \\
\mathrm{RSC} & =\left(\mathrm{CO}_{3}^{2-}+\mathrm{HCO}_{3}^{-}\right)-\left(\mathrm{Ca}^{2+}+\mathrm{Mg}^{2+}\right), \\
\mathrm{SSP} & =\frac{\left(\mathrm{Na}^{+}+\mathrm{K}^{+}\right) \times 100}{\mathrm{Ca}^{2+}+\mathrm{Mg}^{2+}+\mathrm{Na}^{+}+\mathrm{K}^{+}}, \\
\mathrm{KR} & =\frac{\mathrm{Na}^{+}}{\mathrm{Ca}^{2+}+\mathrm{Mg}^{2+}}, \\
\mathrm{Na} & =\frac{\mathrm{Na}^{+} \times 100}{\mathrm{Ca}^{2+}+\mathrm{Mg}^{2+}+\mathrm{Na}^{+}+\mathrm{K}^{+}}, \\
\mathrm{PI} & =\frac{\mathrm{Na}^{+}+\sqrt{\mathrm{HCO}_{3}^{-}}}{\mathrm{Ca}^{2+}+\mathrm{Mg}^{2+}+\mathrm{Na}^{+}} \times 100,
\end{aligned}
$$

where the unit of measurement for all concentrations of cations and anions is milliequivalent per liter (meq/L).

2.4. Statistical Analysis. The seasonal variation of Awash River water quality parameter data was first classified according to the four main seasons (summer, autumn, winter, and spring, each represented by season 1, season 2, season 3 , and season 4 respectively). The sampling month was also selected based on the representation of the month for each season, which was July for summer, October for autumn, January for winter, and April for spring depending on the flow rate of Awash River in each season. Each season's mean and standard deviation of the three-year data for each sampling site and parameter were calculated. Similarly, the overall mean and standard deviation for the whole three-year data were calculated for each parameter and sampling site. The correlation analysis was used to compare the variations and strength of one parameter with the other parameter.

\section{Results and Discussion}

3.1. Physical Quality of Awash River Water. Due to the high flow rate of the Awash River, flooding, and soil erosion from the highlands and suburb agricultural lands, the apparent color of river water samples was high compared to the drainage canal, pond, and deep well water samples. Water turbidity can be attributed to silt and clay microorganisms and various mineral substances. Maximum turbidity was observed during summer due to the high flow rate of the river in which high rainfall is always observed at highlands of the country during this season, and the least turbidity was observed during the dry season. Water samples collected from different sampling sites of Awash River vary in different parameters due to the nature of attributes that interred into the river including springs, canal, ponds, and wastewater. Odor and foam were always observed at Akaki and Mojo sampling sites because in these sampling sites different industries were located and these industries release their wastewater into the river. The odor and foam in these two sampling sites were higher in the dry season compared to the rainy season. This is because the high flow rate during the rainy (summer) season makes dilution of the wastewater in the area.

3.2. Chemical Quality Parameter of Awash River Water. All water quality parameters were measured quarterly (four times a year) by taking samples in each season from July 2016 to July 2019 for three consecutive years. A three-year data for each season was collected to be able to get confidential results, and the mean value was taken for some data analysis. Electrical conductivity (EC), soluble anions $\left(\mathrm{CO}_{3}{ }^{2-}, \mathrm{HCO}_{3}{ }^{-}\right.$, and $\left.\mathrm{Cl}^{-}\right)$, and soluble cations $\left(\mathrm{Na}^{+}, \mathrm{K}^{+}, \mathrm{Ca}^{2+}, \mathrm{Mg}^{2+}\right)$ are the three main chemical characteristics of irrigation water quality [15].

3.2.1. Seasonal Variation of $p H$ across Different Locations. Except for Beseka, Melkasedi, Werer, Ambash, Meteka, and Meteka hot spring sites, water $\mathrm{pH}$ of all other sampling sites 
TABLE 2: Sampling seasons and seasonal flow characteristics.

\begin{tabular}{|c|c|c|c|c|c|c|}
\hline Seasons & \multicolumn{3}{|c|}{ Months in the season } & Season name & Sampling month & Flowing rate \\
\hline Season 1 & June & July & August & Summer & July & High flow \\
\hline Season 2 & September & October & November & Autumn & October & Medium flow \\
\hline Season 3 & December & January & February & Winter & January & Low flow \\
\hline Season 4 & March & April & May & Spring & April & Very low flow \\
\hline
\end{tabular}

was within a permissible limit in each season. However, the overall mean of the three-year data (Table 3 and Figure 2) indicates that only Beseka Lake and Meteka hot spring water exceed the permissible limit set by the WHO [20, 21]. From all the sampling sites, the higher $\mathrm{pH}$ was observed at Beseka Lake followed by Meteka hot spring water. The standard deviation (SD) shows that the least variability of $\mathrm{pH}$ was observed at Beseka Lake. This indicates that the $\mathrm{pH}$ value at Beseka Lake over seasons and years is not significantly variable. Even though the $\mathrm{pH}$ range is specified for irrigation water quality, irrigation water is being able to be buffered by different types of soil, and as a result, $\mathrm{pH}$ of irrigation water is not a basic criterion of water quality, and most crops can tolerate a wide range of $\mathrm{pH}[15]$.

3.2.2. Seasonal Variation of Electrical Conductivity (EC) across Different Locations. EC is a good indicator of total soluble solids or salts present in the water and is highly associated with salinity. EC value at Beseka Lake shows that the water is severely saline for irrigation use according to FAO irrigation water quality classification [15], which ranges from a minimum of 3.24 to a maximum of 5.94 (Table 4). Even though Lake Beseka water is highly saline for irrigation use, the EC value decreases through time, which was $6.75 \mathrm{dS} /$ $\mathrm{m}$ in 2005 and $5.03 \mathrm{dS} / \mathrm{m}$ in 2014 [22], and in this study, the mean EC value in 2016/17, 2017/18, and 2018/19 was $4.38 \mathrm{dS} / \mathrm{m}, 3.55 \mathrm{dS} / \mathrm{m}$, and $3.43 \mathrm{dS} / \mathrm{m}$, respectively. This indicates that the total soluble salt concentration and salinity level of the lake decrease over time. This may be due to the geological activities at Beseka Lake since it takes time to dissolve new rock materials, volcanic rocks, and other elements that contribute to the increment of total soluble salts, expansion, and increment of the lake through time which occupied new places especially in the last seven years, and as a result, they discharge too much water from the Lake to Awash River. On the other hand, even though it does not pass the salinity hazard level set by FAO [15], the comparative increment of EC value was recorded at Melkasedi in the last three years. This may be due to the accumulation of soluble salts in the area through a long time because of largescale irrigation farms, and poor irrigation system makes a favorable condition for the problem. And the effect of Beseka Lake water to the downstream part is observed in Melkasedi, Werer, and Ambash sampling sites because these sites are relatively nearest to the downstream part of Lake Beseka, and the effect decreases as those downstream sampling sites are far from Beseka Lake.

A relatively high EC value was recorded at Meteka hot spring water next to Beseka Lake in comparison with the other sampling sites. EC values at Mojo and Wonji were highly variable from season to season. This indicates that the type and quantity of wastewater discharged from the nearby industries are highly different and vary at different times. $\mathrm{Na}$ concentrations at Beska Lake water are extremely higher in the whole year and followed by Meteka hot spring water. This contributes to the high sodium hazard to the downstream site as sodium adsorption ratio (SAR) and can aggravate soil salinity. $\mathrm{Na}$ concentrations at all sampling sites were positively correlated with $\mathrm{EC}, \mathrm{Cl}^{-}$, and $\mathrm{CO}_{3}{ }^{2-}$. This is because sodium is found in the form of carbonate and bicarbonate $\left(\mathrm{Na}_{2} \mathrm{CO}_{3}\right.$ and $\left.\mathrm{NaHCO}_{3}\right)$ and in the form of chloride $(\mathrm{NaCl})$. It also contributes to the increment of EC since sodium ion is a positively charged ion.

The statistical data shows that relatively higher variability of EC over seasons and years was observed at the upper and middle Awash River Basin compared to the lower basin. The highest SD is observed at Wonji, Mojo, and Beseka, respectively. This is due to different types and amounts of industrial effluents at Wonji and Mojo discharged into the river at different times, and the variability at Beseka is due to the reduction of EC through time which makes the variability higher.

\subsubsection{Seasonal Variation of $\mathrm{Na}(\mathrm{meq} / \mathrm{L})$ across Different} Locations. A large amount of sodium ( $\mathrm{Na}$ ) concentration in irrigation water is a special concern due to its effect on soil, which makes the soil disperse and makes the soil have poor physical properties. Na concentration varies at different sampling sites because different tributaries, industrial waste, and agricultural activities affect the quality of water in a different content. The overall mean of the three-year data as well as each season and yearly data indicates that Beseka Lake water has the highest concentration of $\mathrm{Na}$, followed by Meteka hot spring water (Table 5 and Figure 3).

\subsubsection{Seasonal Variation of $K(\mathrm{meq} / \mathrm{L})$ across Different} Locations. Potassium $(\mathrm{K})$ concentration is relatively higher at the upper Awash River Basin compared to the middle and lower basin. Beseka and Meteka hot spring sampling sites have higher $\mathrm{K}$ concentrations from the middle and lower Awash River Basin, respectively. However, unlike other irrigation water quality parameters, $\mathrm{K}$ concentration shows the least variability across sampling sites. SD of the threeyear data for $\mathrm{K}$ was very small across different locations and seasons which ranges from a minimum of 0.06 to a maximum of 0.29 . This shows that $\mathrm{K}$ variability across sampling sites over years and seasons is very small compared with the other irrigation water quality parameters. However, comparing with location, $\mathrm{K}$ concentration at Beseka Lake water was maximum ( $0.51 \mathrm{meq} / \mathrm{L}$ from the three-year mean value), 


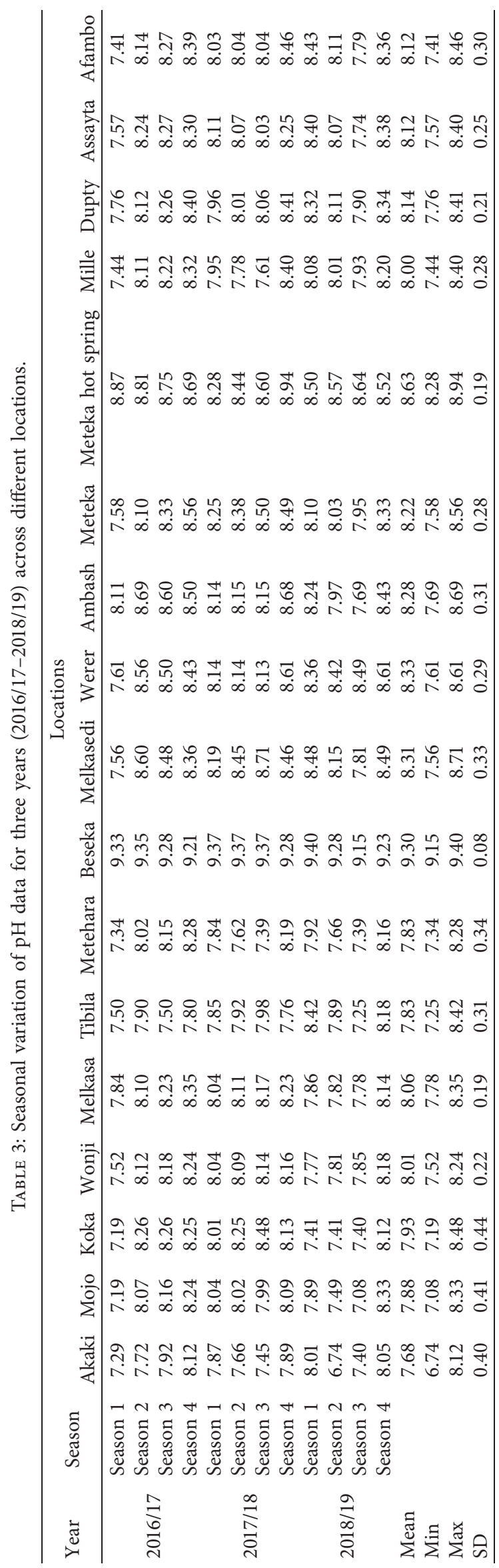




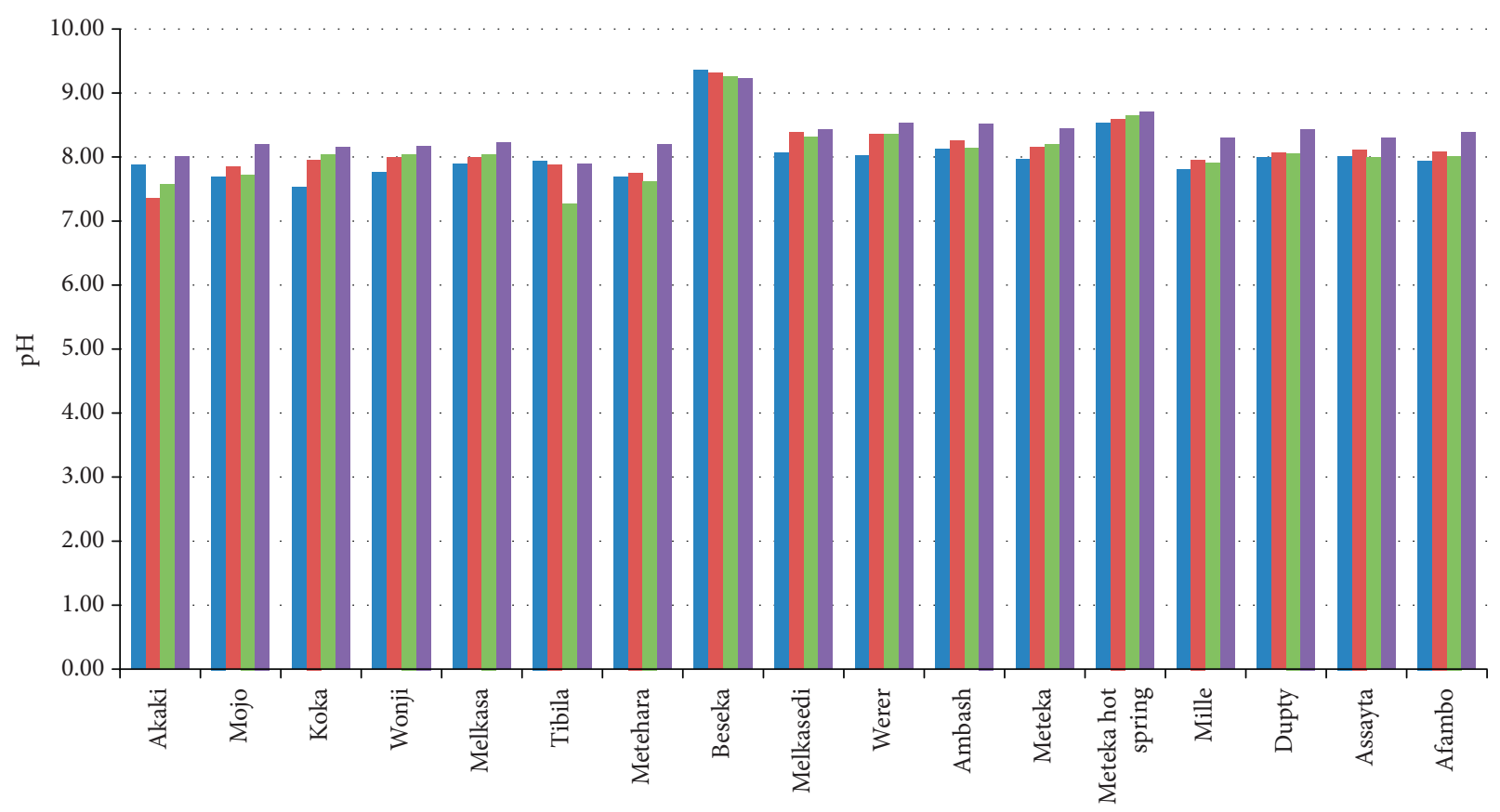

Sampling sites

- Season 1

- Season 2

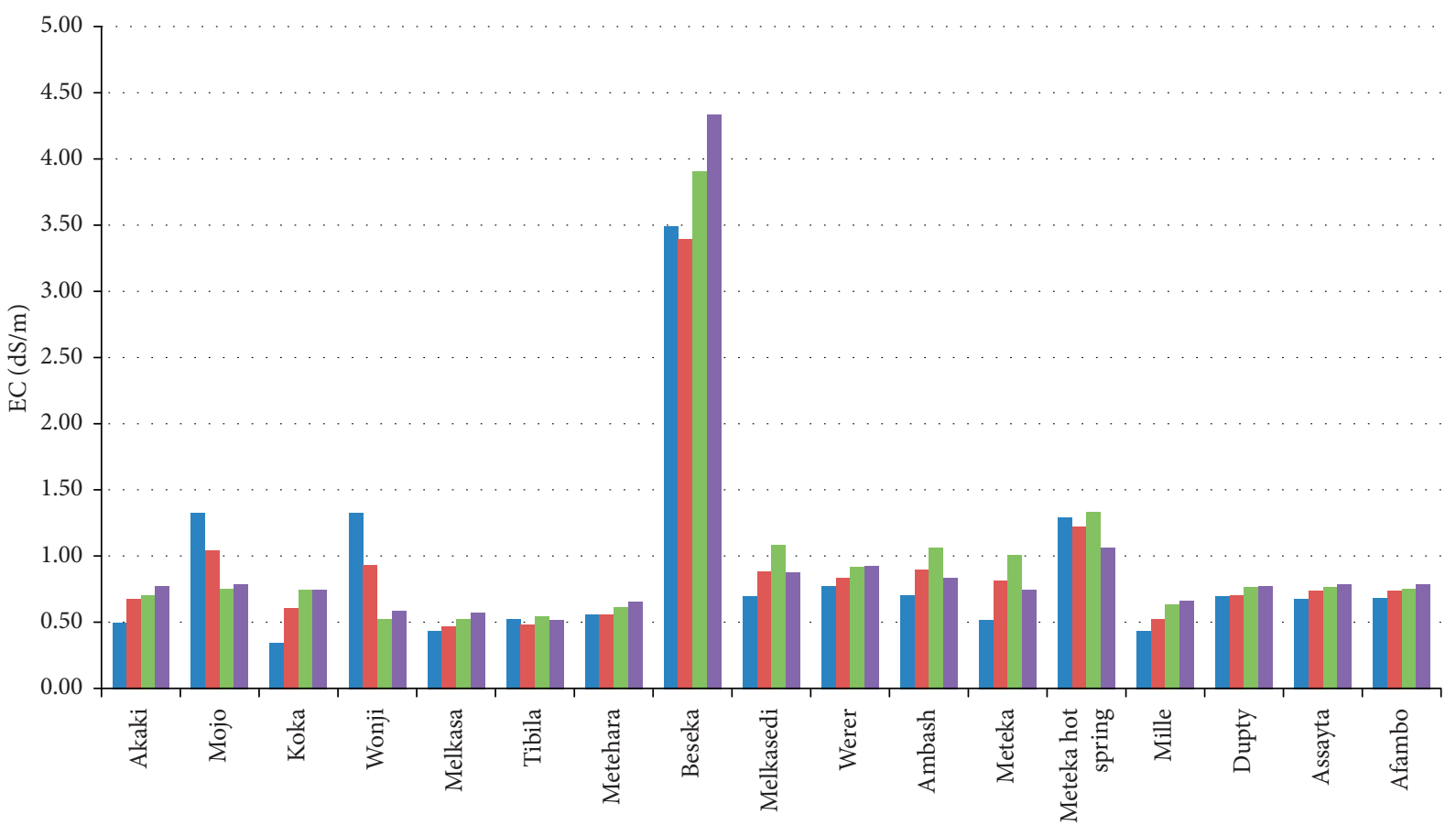

Sampling sites

- Season 1

- Season 2

$$
\text { - Season } 3
$$$$
\text { - Season } 4
$$

(a)

$$
\begin{array}{r}
\text { Season } 3 \\
\text { Season } 4
\end{array}
$$

(b)

Figure 2: Continued. 


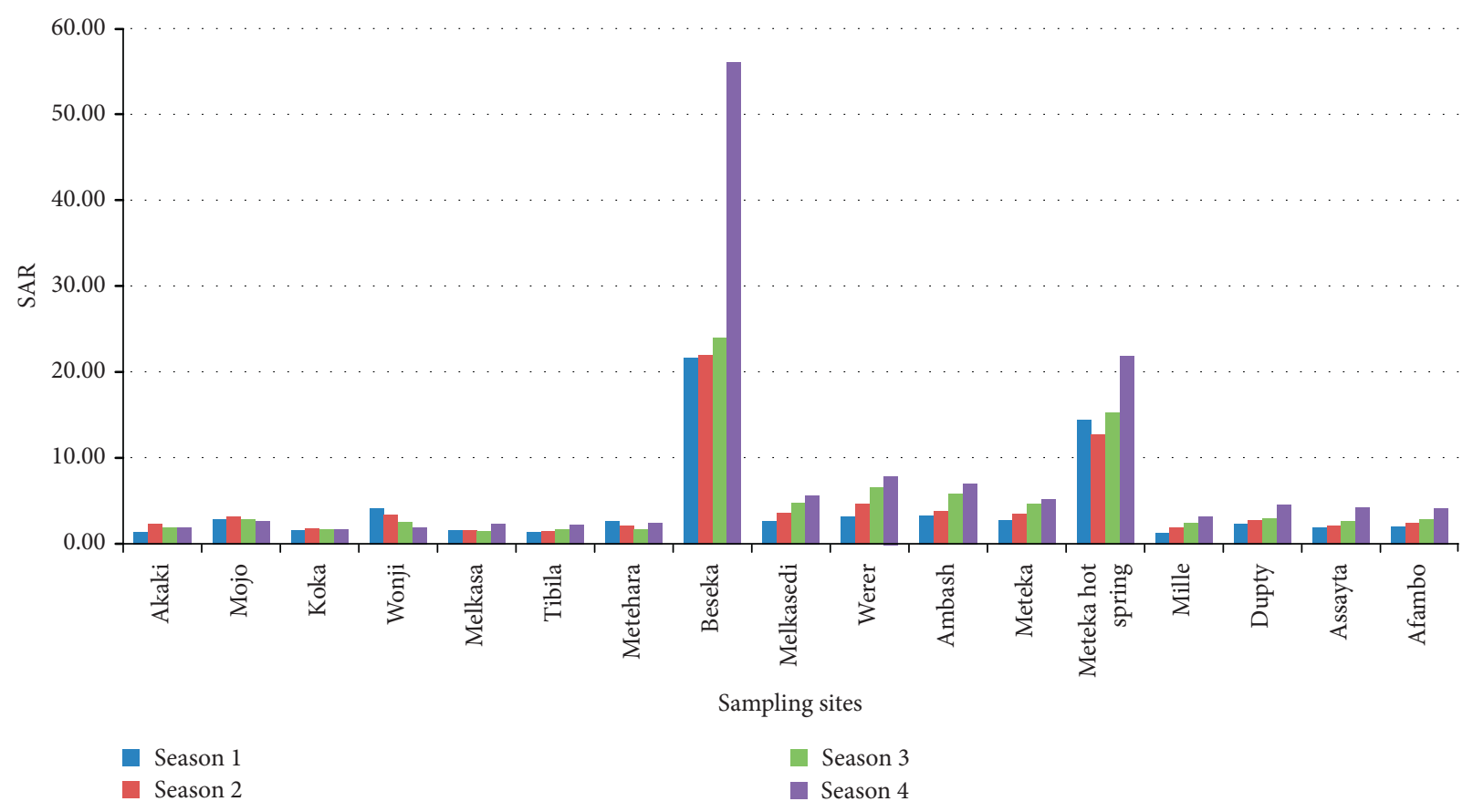

(c)

Figure 2: Mean seasonal variation of pH across different locations over years (2016/17-2018/19).

and the minimum concentration was observed at Mille $(0.06 \mathrm{meq} / \mathrm{L}$ from the three-year mean value).

\subsubsection{Seasonal Variation of $\mathrm{Ca}+\mathrm{Mg}(\mathrm{meq} / \mathrm{L})$ across Different} Locations. Unlike other irrigation water quality parameters, the least amount of $\mathrm{Ca}$ and $\mathrm{Mg}$ was recorded at Meteka hot spring and Beseka Lake water. This shows that $\mathrm{Ca}$ and $\mathrm{Mg}$ negatively correlated with $\mathrm{Na}$ concentration, EC, and $\mathrm{SAR}$ values. This is because when the concentration of $\mathrm{Na}$ is high, it replaces $\mathrm{Ca}$ and $\mathrm{Mg}$ in the ionic compounds such as $\mathrm{CaCO}_{3}, \mathrm{Ca}\left(\mathrm{HCO}_{3}\right)_{2}, \mathrm{MgCO}_{3}$, and $\mathrm{Mg}\left(\mathrm{HCO}_{3}\right)_{2}$, and it forms the corresponding ionic compounds of $\mathrm{Na}$ such as $\mathrm{Na}_{2} \mathrm{CO}_{3}$ and $\mathrm{NaHCO}_{3}$ which leaves water-insoluble precipitate of $\mathrm{Ca}$ and $\mathrm{Mg}$. The maximum concentration of $\mathrm{Ca}$ and $\mathrm{Mg}$ was observed at Akaki followed by Mille, Assayta, and Mojo, and the minimum concentration of $\mathrm{Ca}$ and $\mathrm{Mg}$ was recorded at Meteka hot spring and Beseka Lake (Table 6).

3.2.6. Seasonal Variation of Sodium Adsorption Ratio (SAR) across Different Locations. Sodium hazard on soil due to poor irrigation and contamination of water was observed by the value of SAR. SAR is one of the water quality parameters which is a useful index for predicting water sodicity level and indicates the tendency of salt solution to produce excessive exchangeable sodium in soil [23]. Because SAR is directly proportional to $\mathrm{Na}$ concentration and inversely proportional to $\mathrm{Ca}+\mathrm{Mg}$, Beseka and Meteka hot spring water contains the highest SAR in which the mean of the three-year data was 41.03 and 16.13 for each, respectively (Figure 2(c)). The upstream locations of Awash River water have lower SAR values compared to middle and lower streams.

The highest variability of SAR over seasons and years is observed at Beseka Lake which positively correlated with EC and Na concentration, and the maximum SAR was observed at a very dry season which is represented by season 3 and season 4, and the minimum SAR was observed during high flow season which is represented by season 1 and season 2 (Table 7). This is because high rainfall and other types of water from the surrounding of Beseka Lake make dilution to the lake and reduce $\mathrm{Na}$ concentration during high water flow time.

3.2.7. Seasonal Variation of Soluble Anions $\left(\mathrm{CO}_{3}{ }^{2-}, \mathrm{HCO}_{3}{ }^{-}\right.$, and $\mathrm{Cl}^{-}$in meq/L) across Different Locations. The concentration of carbonates $\left(\mathrm{CO}_{3}{ }^{2-}\right)$ and bicarbonates $\left(\mathrm{HCO}_{3}{ }^{-}\right)$in irrigation water makes insoluble precipitation of calcium carbonate $\left(\mathrm{CaCO}_{3}\right)$ and magnesium carbonate $\left(\mathrm{MgCO}_{3}\right)$; on the other hand, chloride $\left(\mathrm{Cl}^{-}\right)$is the most toxic ion to some plant species which inhibit plant growth when the concentration is high [15]. Maximum $\mathrm{CO}_{3}{ }^{2-}$ ion concentration was observed at Beseka followed by Melkasedi, Meteka, and Meteka hot spring, respectively. At the two sites (Beseka and Melkasedi), all water-soluble anions $\left(\mathrm{CO}_{3}{ }^{2-}, \mathrm{HCO}_{3}{ }^{-}\right.$, and $\mathrm{Cl}^{-}$) were maximum compared to other sampling sites throughout all seasons and years (Figure 3). $\mathrm{HCO}_{3}{ }^{-}$concentration at Beseka, Ambash, and Melkasedi was extremely high. This shows that the geochemical composition of carbonate and bicarbonate is dominant in these areas. On the other hand, the maximum concentration of $\mathrm{Cl}^{-}$ion was recorded at Melkasedi and Beseka followed by Akaki and 


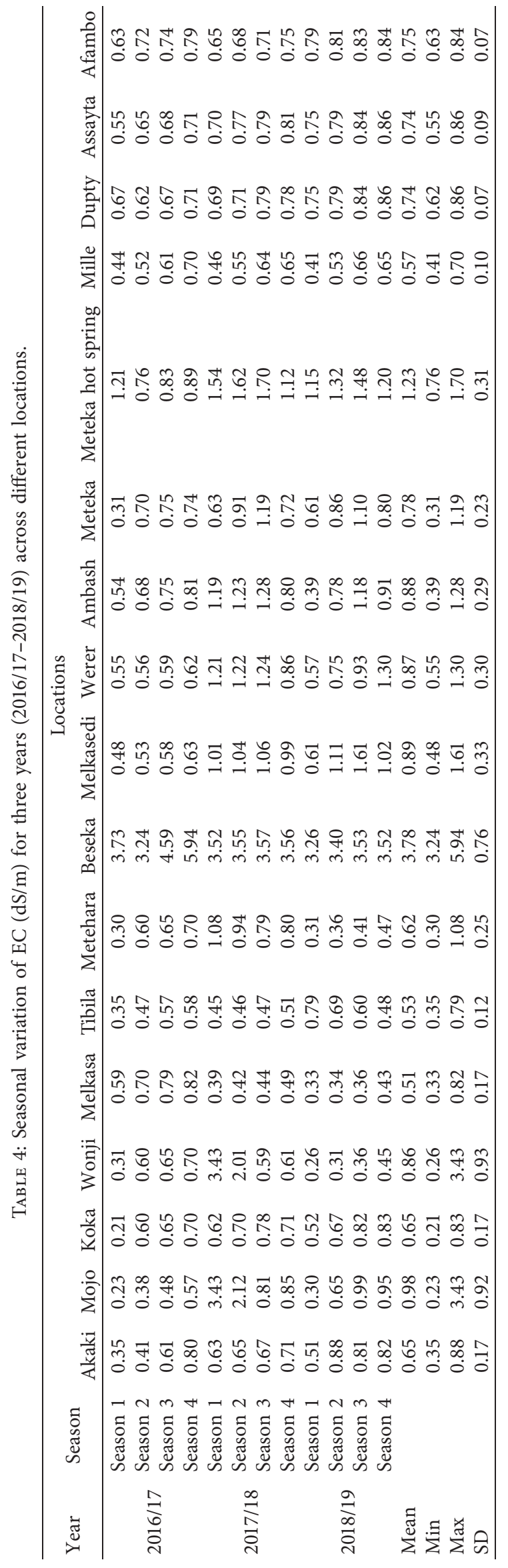




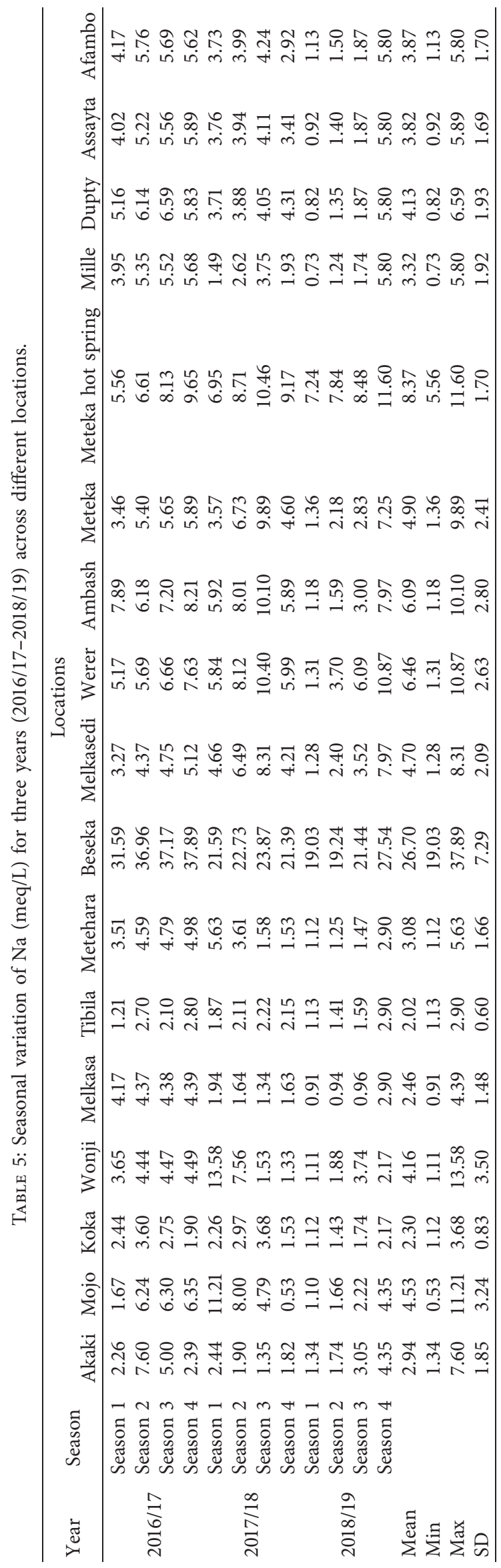




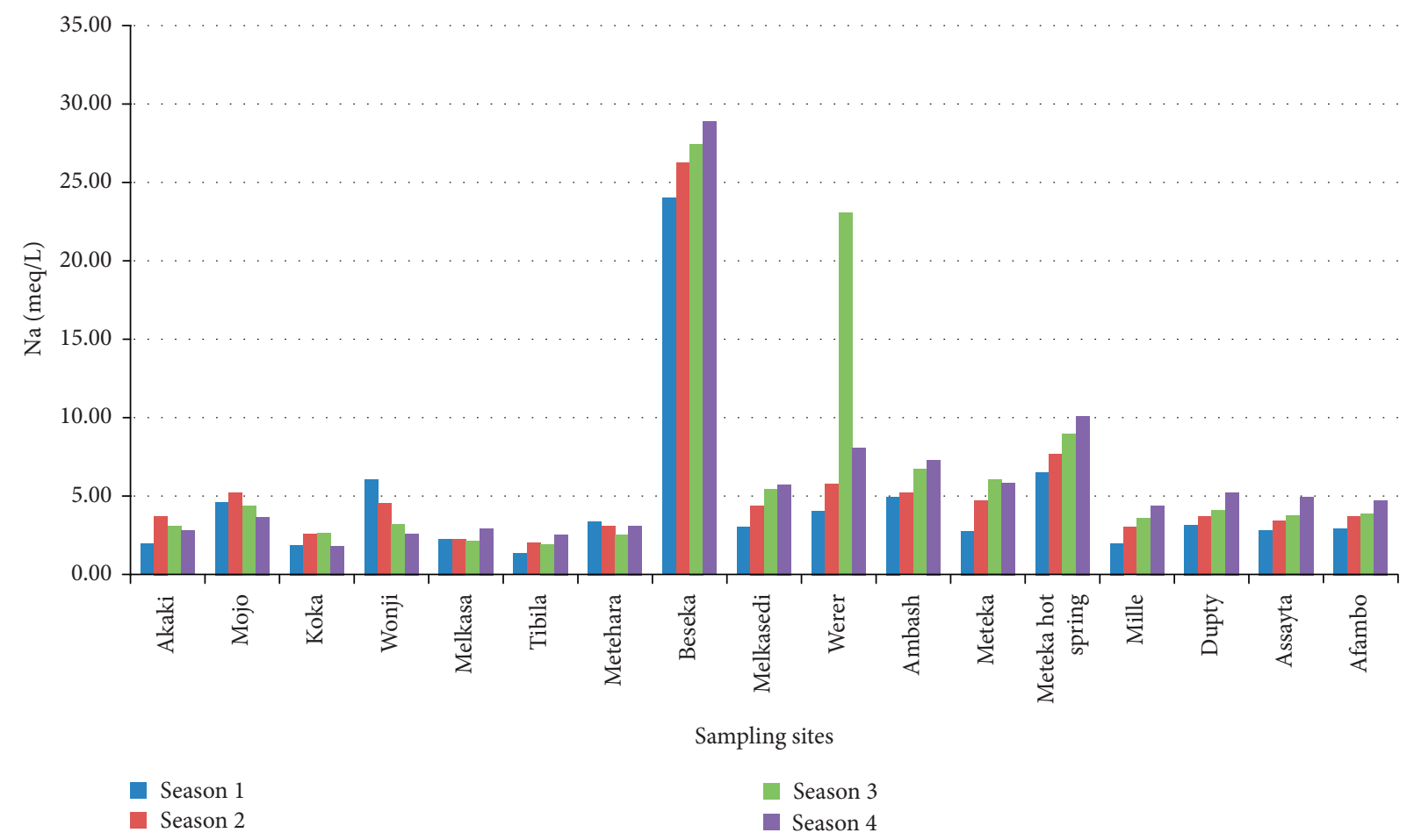

(a)

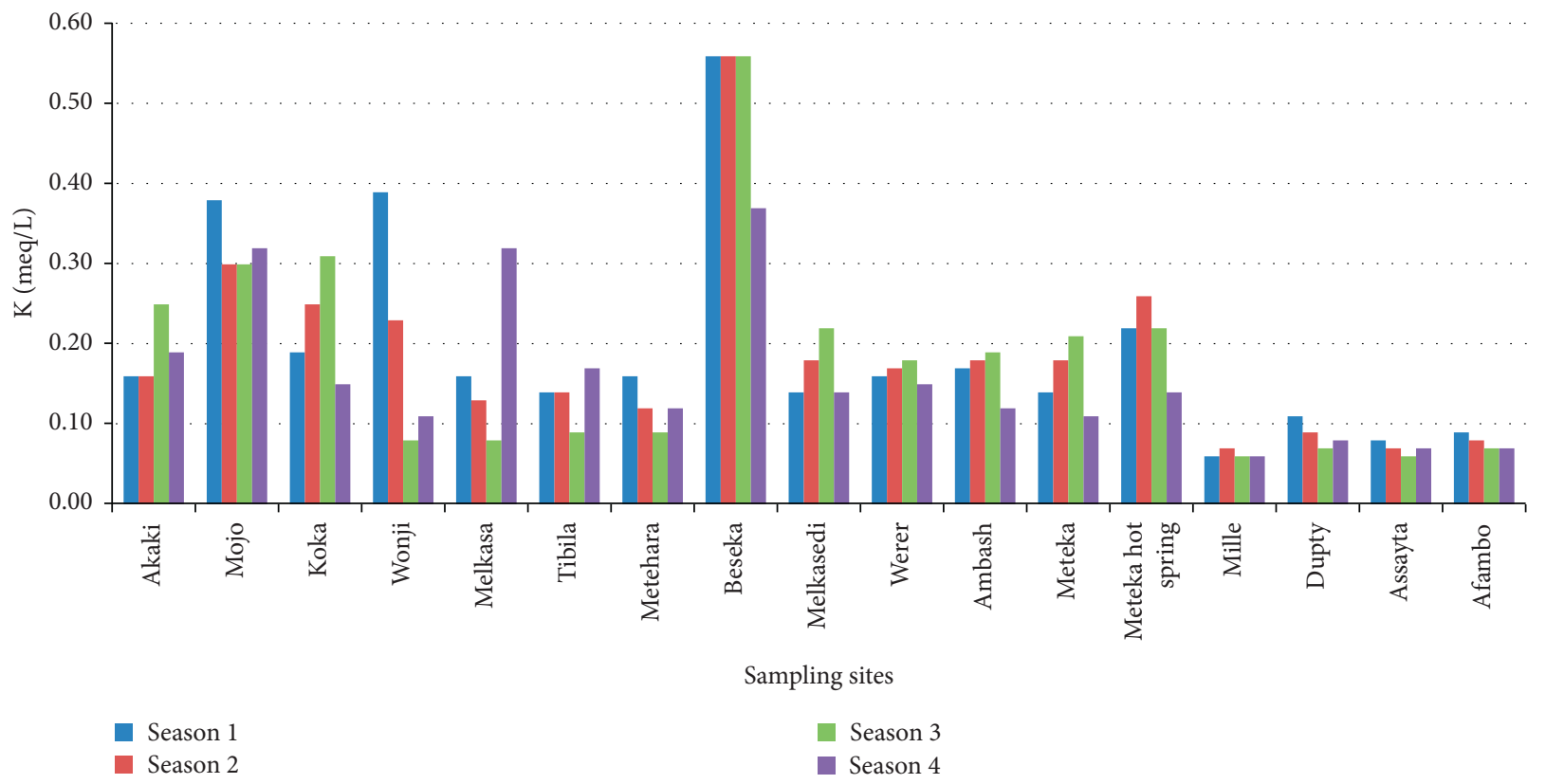

(b)

Figure 3: Mean seasonal variation of Na across different locations over years (2016/17-2018/19).

Wonji, respectively. This has a positive correlation with $\mathrm{Na}$ and $\mathrm{EC}$ values in these areas. This is because $\mathrm{Cl}^{-}$ion is found in the form of $\mathrm{NaCl}$.

3.2.8. Seasonal Variation of Residual Sodium Carbonate (RSC) across Different Locations. RSC is an indication of the alkalinity of irrigation water and it is a combined effect of
$\mathrm{HCO}_{3}{ }^{-}+\mathrm{CO}_{3}{ }^{2-}$ relative to $\mathrm{Ca}+\mathrm{Mg}$ ions. The overall mean of the three-year data shows that RSC was extremely high at Beseka followed by Melkasedi, Meteka hot spring, Ambash, Meteka, Mojo, Werer, Assayta, Wonji, Dupty, Tibila, Metehara, and Afambo, respectively (Figure 4). At most sampling sites, RSC positively correlates with EC and SAR. This shows that at high alkalinity and sodicity, RSC also becomes higher. The mean of the three-year data reveals that 


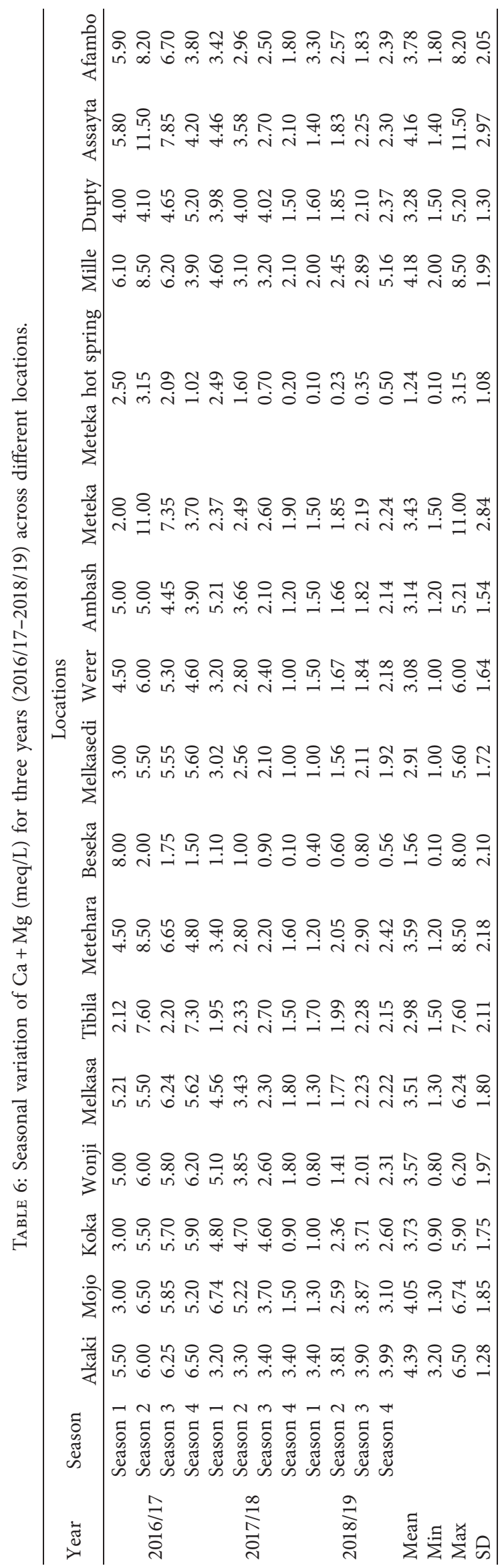




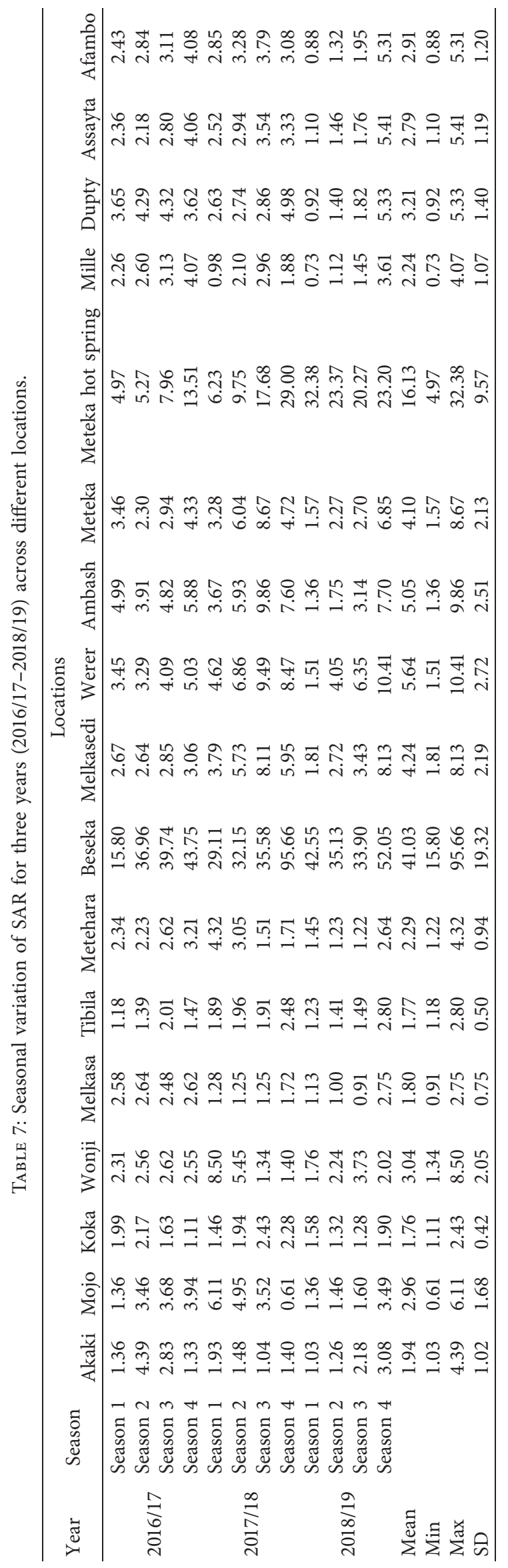




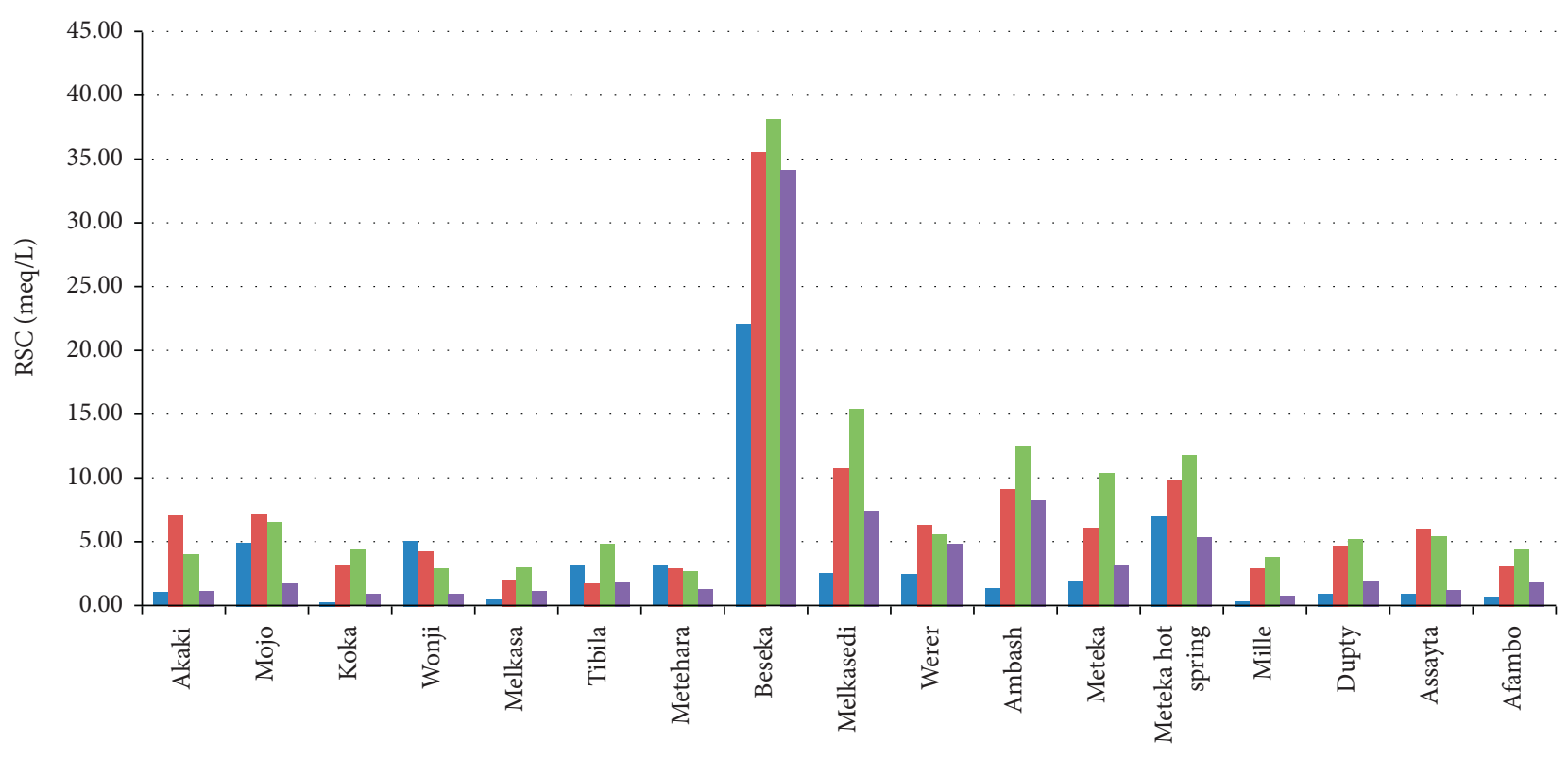

Sampling sites

Season 1
Season 2

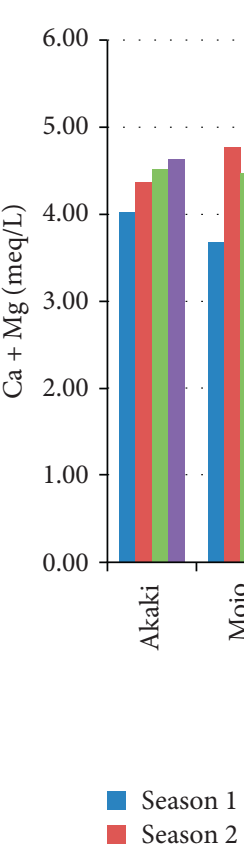

- Season 3

- Season 4

(a) 


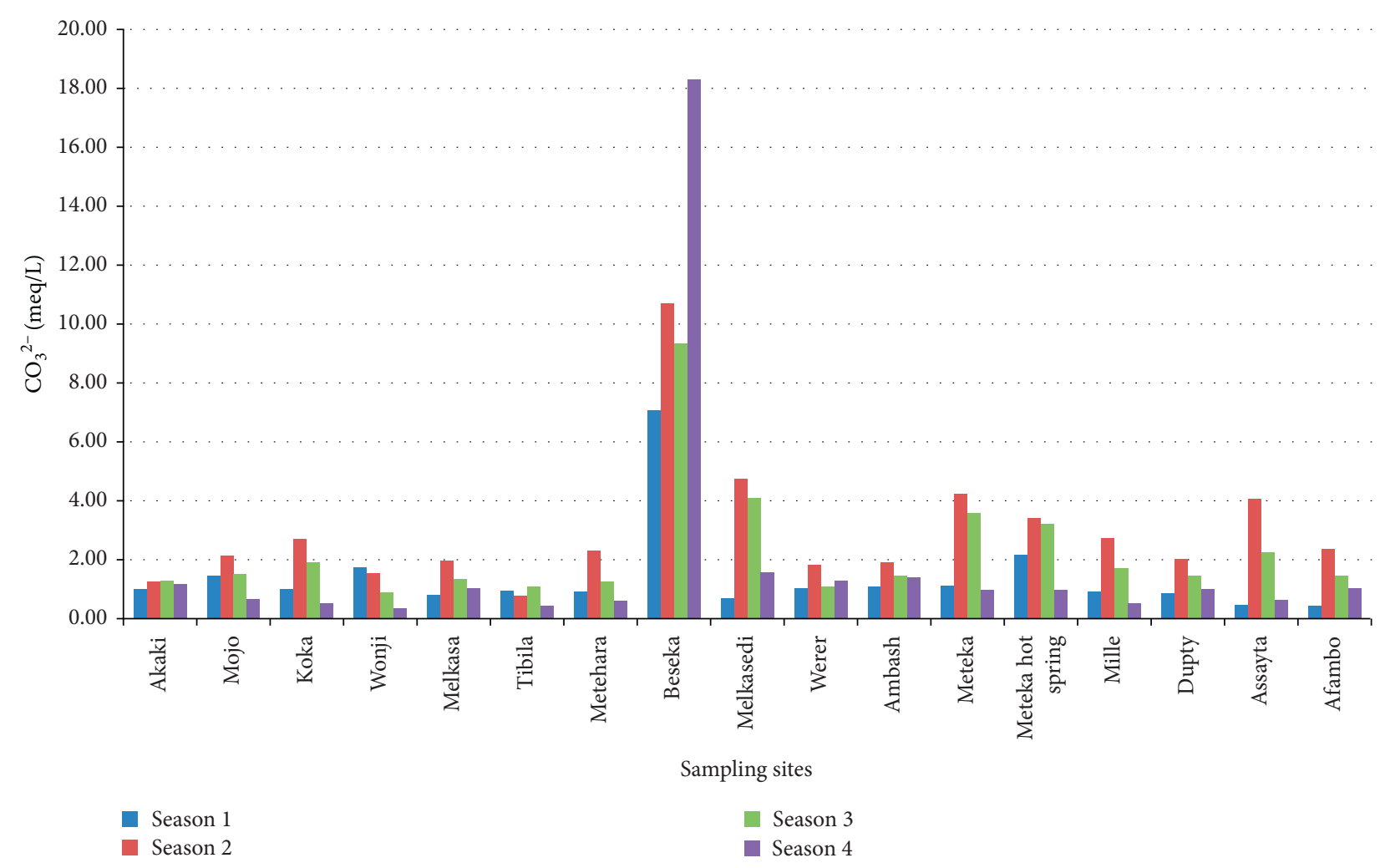

(c)
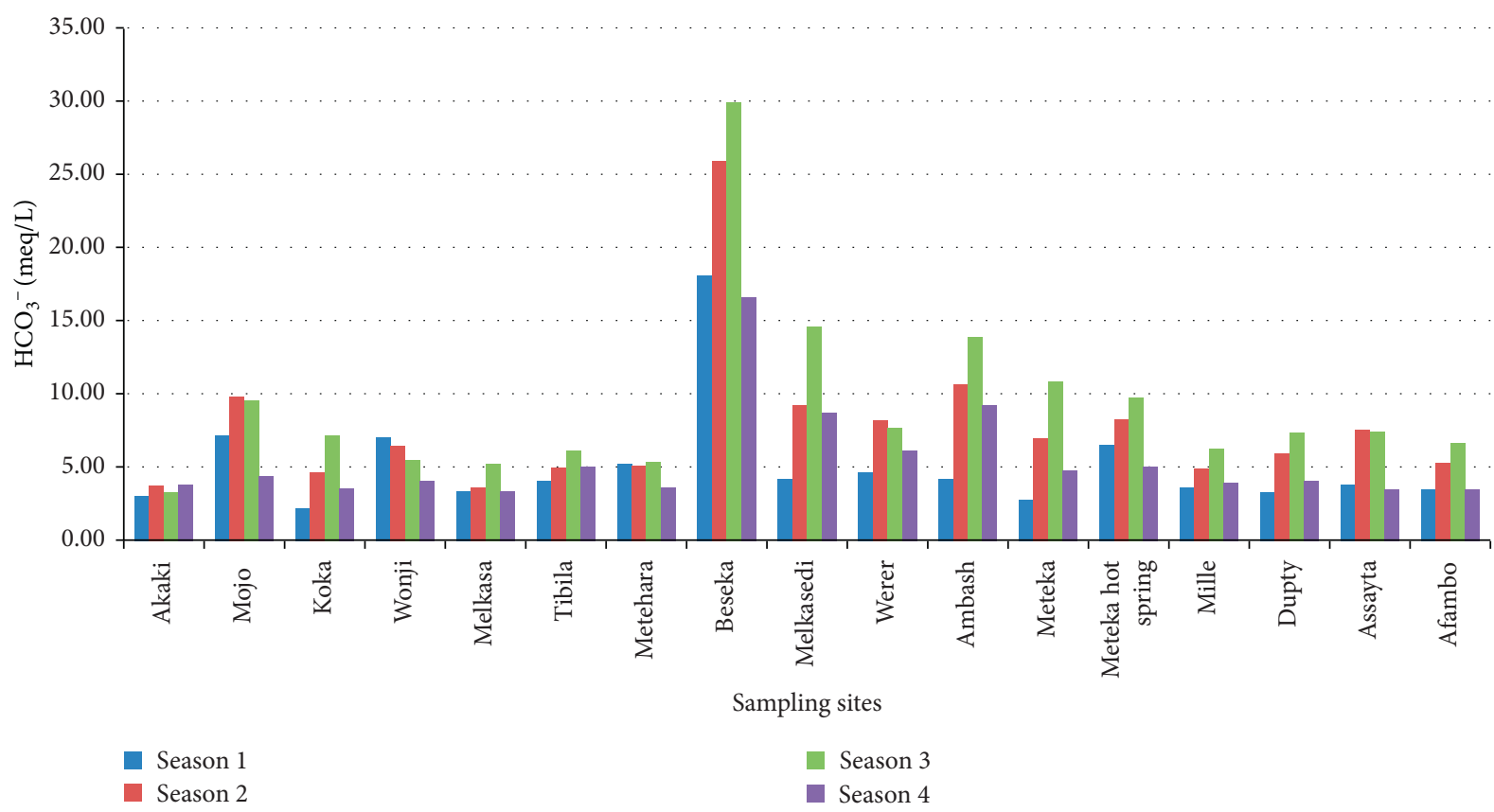

Sampling sites

Season 1

- Season 3

- Season 4

(d)

Figure 4: Continued. 


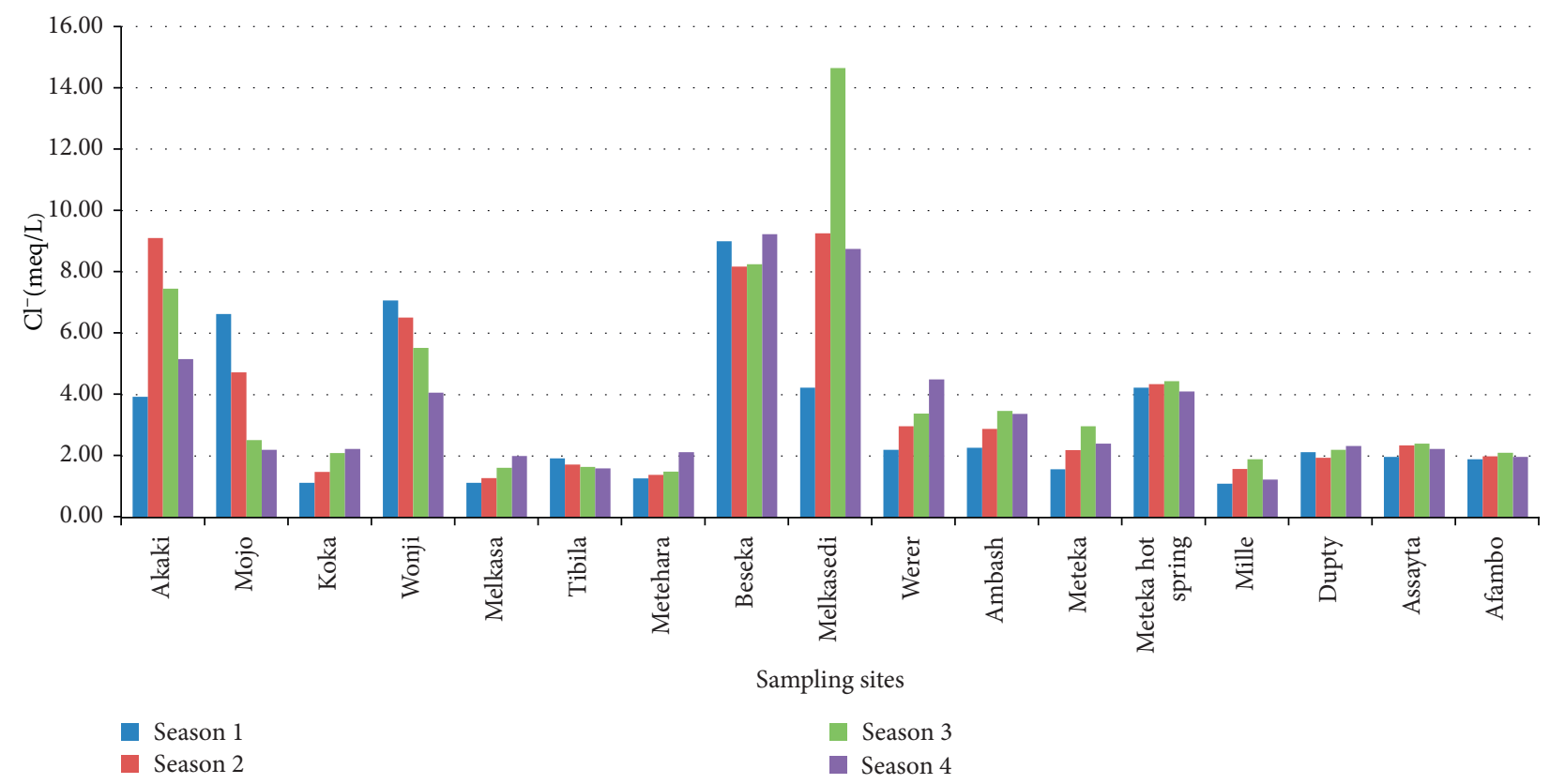

(e)

FIgURE 4: Mean seasonal variation of RSC across different locations over years (2016/17-2018/19).

RSC at Beseka, Melkasedi, Meteka hot spring, Ambash, Meteka, Mojo, Werer Assayta, Wonji, Dupty, Tibila, and Afambo sites is above a permissible level (Table 8).

3.2.9. Classification of Water Quality Indicators for Irrigational Use. In all water quality parameters, Beseka Lake water is unsuitable for irrigation purposes. Next to Beseka Lake water, Meteka hot spring water is unsuitable for irrigation purposes since the majority of irrigation water quality parameters are above the permissible limit (Table 9). Even though Meteka hot spring water possesses a risk of irrigation water quality by most quality parameters, the amount of water that flows from the spring and joins Awash River water is very low and the risk will not be significant. However, it has its own contribution to aggravate salinity for a long time for irrigation farms in the area. A significant amount of water from Beseka Lake flows and joins the Awash River. Its contribution to the increment of irrigation water quality parameters to the downstream site is observed. Therefore, its effect to aggravate salinity to downstream farms is undeniable. The standards of various countries and organizations for major irrigation water quality indicators such as EC, SAR, and RSC are described in Table $9([15,19,20,24-26])$.

3.2.10. Overall Irrigation Water Quality Parameters of Awash River Water across Different Locations from Three-Year Data (2016/17-2018/19). The overall water quality parameter data of the three years reveal that Beseka Lake water is unsuitable for irrigation and has high salinity and alkalinity level by all water quality criteria of irrigation water. Meteka hot spring water is also classified as medium alkalinity level; however, the amount of water that flows out from the site is small and has no significant effect on salinity aggravation compared to the total flow of Awash River water, and if appropriate leaching is done, it can be used for irrigation. Except for $\mathrm{Ca}$ and $\mathrm{Mg}$, all the other irrigation water quality parameters were higher at Beseka Lake compared to the other sites. The higher soluble sodium percentage and sodium percentage $(95.29 \%$ and $93.29 \%$, respectively) also indicated that $\mathrm{Na}$ is the dominant cation in the lake for which the water is highly alkaline (Table 10). The higher soluble anion concentration $\left(\mathrm{CO}_{3}{ }^{2-}\right.$, 


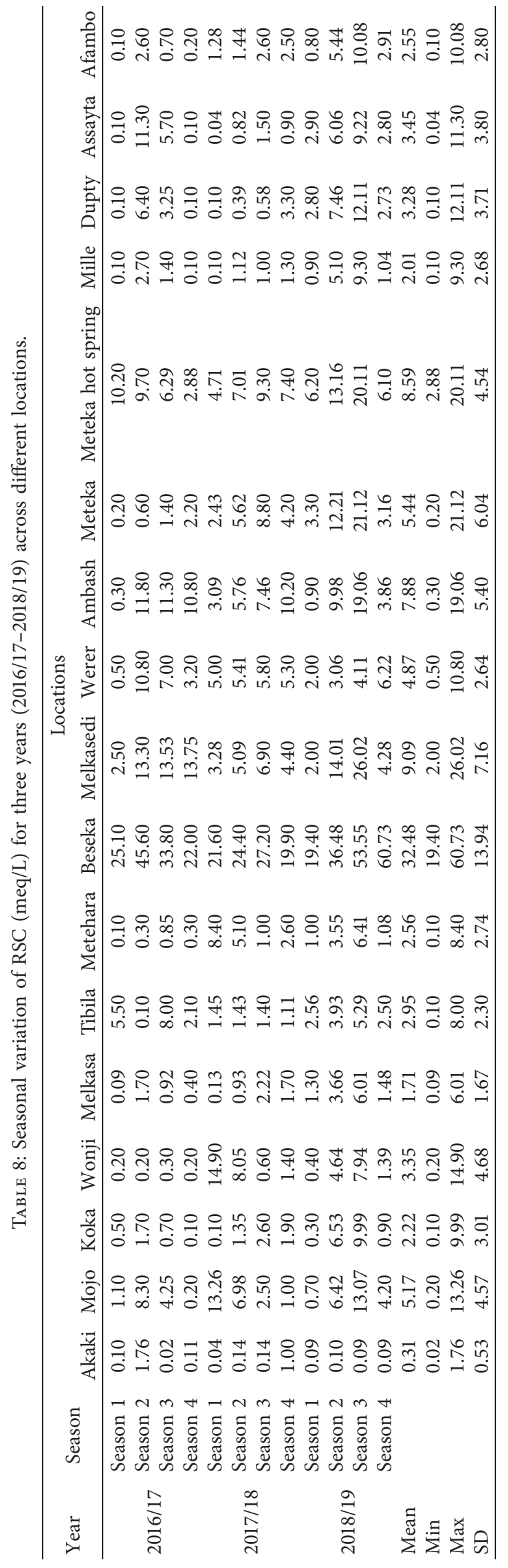


TABle 9: Classification of irrigation water quality.

\begin{tabular}{|c|c|c|c|}
\hline Parameter & Range & Classification & References \\
\hline $\mathrm{pH}$ & $\begin{array}{l}<6.5 \\
6.5-8.4 \\
>8.4\end{array}$ & $\begin{array}{l}\text { Acidic } \\
\text { Permissible } \\
\text { Alkaline }\end{array}$ & {$[20,21]$} \\
\hline $\mathrm{EC}(\mathrm{dS} / \mathrm{m})$ & $\begin{array}{c}<0.25 \\
0.25-0.75 \\
0.75-2.25 \\
2.25-4 \\
4-6 \\
>6\end{array}$ & $\begin{array}{c}\text { Low saline (totally safe) } \\
\text { Moderately saline (safe) } \\
\text { Medium-to-high salinity (leaching required) } \\
\text { High salinity (unsafe) } \\
\text { Very high salinity (unsafe) } \\
\text { Excessive salinity (severe) }\end{array}$ & {$[15,19,20,24,25]$} \\
\hline SAR & $\begin{array}{c}<10 \\
10-18 \\
18-26 \\
>26\end{array}$ & $\begin{array}{c}\text { Low (excellent) } \\
\text { Medium (good) } \\
\text { High (doubtful) } \\
\text { Very high (unsuitable) }\end{array}$ & {$[15,19,24,25]$} \\
\hline $\mathrm{HCO}_{3}{ }^{-}$ & $\begin{array}{l}<1.5 \\
1.5-8.5 \\
>8.5\end{array}$ & $\begin{array}{l}\text { Normal } \\
\text { Slight to moderate } \\
\text { Severe }\end{array}$ & {$[25]$} \\
\hline $\mathrm{Cl}^{-}$ & $\begin{array}{c}<2 \\
2-4 \\
4-10 \\
>10\end{array}$ & $\begin{array}{c}\text { None (generally safe for all plants) } \\
\text { Slight to moderate (sensitive plants usually show slight to moderate injury) } \\
\text { High (moderately tolerant plants usually show slight to substantial injury) } \\
\text { Very high (can cause severe problems) }\end{array}$ & {$[15,20,25]$} \\
\hline $\operatorname{RSC}(\mathrm{meq} / \mathrm{L})$ & $\begin{array}{l}<1.25 \\
1.25-2.5 \\
>2.5\end{array}$ & $\begin{array}{c}\text { Safe } \\
\text { Marginal } \\
\text { Unsuitable }\end{array}$ & {$[15,25]$} \\
\hline
\end{tabular}

TABLE 10: Mean values of three-year irrigation water quality parameters of Awash River water.

\begin{tabular}{|c|c|c|c|c|c|c|c|c|c|c|c|c|c|}
\hline \multirow{2}{*}{ Locations } & \multicolumn{13}{|c|}{ Quality parameters $\left(\mathrm{EC}(\mathrm{dS} / \mathrm{m}), \mathrm{Na}^{+}, \mathrm{K}^{+}, \mathrm{Ca}+\mathrm{Mg}, \mathrm{CO}_{3}{ }^{2-}, \mathrm{HCO}_{3}{ }^{-}, \mathrm{Cl}^{-}, \mathrm{RSC}(\mathrm{meq} / \mathrm{L})\right)$} \\
\hline & $\mathrm{pH}$ & $\mathrm{EC}_{\mathrm{w}}$ & $\mathrm{Na}$ & $\mathrm{K}$ & $\mathrm{Ca}+\mathrm{Mg}$ & $\mathrm{CO}_{3}{ }^{2-}$ & $\mathrm{HCO}_{3}{ }^{-}$ & $\mathrm{Cl}^{-}$ & SAR & RSC & SSP & $\mathrm{KR}$ & $\% \mathrm{Na}$ \\
\hline Akaki & 7.68 & 0.65 & 2.94 & 0.21 & 4.39 & 1.19 & 3.51 & 6.41 & 1.94 & 0.31 & 39.92 & 0.65 & 36.72 \\
\hline Mojo & 7.88 & 0.98 & 4.53 & 0.32 & 4.05 & 2.48 & 7.77 & 4.02 & 2.96 & 5.17 & 49.72 & 1.01 & 46.37 \\
\hline Koka & 7.93 & 0.65 & 2.30 & 0.22 & 3.73 & 1.85 & 4.41 & 1.74 & 1.76 & 2.22 & 42.87 & 0.74 & 39.13 \\
\hline Wonji & 8.01 & 0.86 & 4.16 & 0.20 & 3.57 & 1.51 & 5.79 & 5.79 & 3.04 & 3.35 & 52.41 & 1.20 & 50.14 \\
\hline Melkassa & 8.06 & 0.51 & 2.46 & 0.17 & 3.51 & 1.41 & 3.93 & 1.51 & 1.80 & 1.71 & 42.18 & 0.70 & 38.75 \\
\hline Tibila & 7.82 & 0.53 & 2.02 & 0.13 & 2.98 & 0.82 & 5.11 & 1.72 & 1.77 & 2.95 & 44.87 & 0.82 & 42.00 \\
\hline Metehara & 7.83 & 0.62 & 3.08 & 0.12 & 3.59 & 1.70 & 4.87 & 1.57 & 2.29 & 2.56 & 47.44 & 0.91 & 45.22 \\
\hline Beseka & 9.30 & 3.78 & 26.70 & 0.51 & 1.56 & 11.35 & 22.69 & 8.67 & 41.03 & 32.48 & 95.29 & 42.28 & 93.29 \\
\hline Melkasedi & 8.31 & 0.89 & 4.70 & 0.17 & 2.91 & 2.78 & 9.22 & 9.22 & 4.24 & 9.09 & 62.90 & 2.04 & 60.27 \\
\hline Werer & 8.33 & 0.87 & 6.46 & 0.16 & 3.08 & 1.43 & 6.72 & 3.26 & 5.64 & 4.87 & 67.46 & 2.62 & 65.53 \\
\hline Ambash & 8.28 & 0.88 & 6.09 & 0.16 & 3.14 & 1.47 & 9.54 & 3.00 & 5.05 & 7.88 & 64.97 & 2.22 & 62.59 \\
\hline Meteka & 8.22 & 0.78 & 4.90 & 0.16 & 3.43 & 2.48 & 6.38 & 2.28 & 4.10 & 5.44 & 60.83 & 1.80 & 58.49 \\
\hline Meteka hot spring & 8.63 & 1.23 & 8.37 & 0.21 & 1.24 & 2.45 & 7.43 & 4.28 & 16.13 & 8.59 & 87.33 & 20.12 & 85.19 \\
\hline Mille & 8.00 & 0.57 & 3.32 & 0.06 & 4.18 & 1.78 & 4.72 & 1.45 & 2.24 & 2.01 & 42.86 & 0.79 & 41.90 \\
\hline Dupty & 8.14 & 0.74 & 4.13 & 0.09 & 3.28 & 1.46 & 5.20 & 2.15 & 3.21 & 3.28 & 54.42 & 1.31 & 52.92 \\
\hline Assayta & 8.12 & 0.74 & 3.82 & 0.07 & 4.16 & 2.23 & 5.62 & 2.24 & 2.79 & 3.45 & 50.03 & 1.09 & 48.74 \\
\hline Afambo & 8.12 & 0.75 & 3.87 & 0.08 & 3.78 & 1.76 & 4.76 & 1.99 & 2.91 & 2.55 & 51.13 & 1.16 & 49.96 \\
\hline Min & 7.68 & 0.51 & 2.02 & 0.06 & 1.24 & 0.82 & 3.51 & 1.45 & 1.76 & 0.31 & 39.92 & 0.65 & 36.72 \\
\hline Max & 9.30 & 3.78 & 26.70 & 0.51 & 4.39 & 11.35 & 22.69 & 9.22 & 41.03 & 32.48 & 95.29 & 42.28 & 93.29 \\
\hline
\end{tabular}

$\mathrm{HCO}_{3}{ }^{-}$, and $\mathrm{Cl}^{-}$) indicates that the dominant $\mathrm{Na}$ cation is found in the form of $\mathrm{Na}_{2} \mathrm{CO}^{3}, \mathrm{NaHCO}_{3}$, and $\mathrm{NaCl}$.

\section{Conclusion}

The major parameters including $\mathrm{pH}, \mathrm{EC}, \mathrm{SAR}, \mathrm{RSC}, \mathrm{Na}^{+}, \mathrm{K}^{+}$, $\mathrm{CO}_{3}{ }^{2-}, \mathrm{HCO}_{3}{ }^{-}, \mathrm{Cl}^{-}$, and $\mathrm{Ca}+\mathrm{Mg}$ were an important tool used to evaluate the irrigation water quality of the studied area. In this study, it was observed that $\mathrm{pH}$ was above the permissible limit only at Beseka Lake and Meteka hot spring water. SAR and EC values also indicated that Beseka Lake and Meteka hot spring water is high in sodicity and alkalinity, especially Beseka Lake water is severely saline for irrigation use, while the upstream locations of Awash River water have lower SAR values compared to middle and lower streams. The overall mean of the three-year data shows that 
RSC was extremely high at Beseka followed by Melkasedi, Meteka hot spring, Ambash, Meteka, Mojo, Werer, Assayta, Wonji, Dupty, Tibila, Metehara, and Afambo, respectively, and at most of these sampling sites, RSC positively correlates with EC and SAR. The overall quality parameter data shows that Beseka Lake water quality is extremely severe for irrigation. Meteka hot spring water shows a medium salinity and sodicity level; as a result, the water cannot be used for irrigation directly unless proper management is taken. However, the amount of water that flows from Meteka hot spring and joins Awash River water is very small, and it will not have a significant effect as causing serious salinity. $\mathrm{Na}$ concentration varies at different sampling sites because different tributaries, industrial waste, and agricultural activities affect the quality of water in a different content. From upstream sampling sites, a relatively high concentration in most irrigation water quality was observed at Akaki, Mojo, and Wonji, which can be associated with the release of industrial waste in these areas because most industries are found in these areas. The concentration of $\mathrm{K}$ is relatively higher at the upper Awash River Basin compared to the middle and lower basin; however, $\mathrm{K}$ shows the least variability across sampling sites. The concentrations of $\mathrm{CO}_{3}{ }^{2-}$ and $\mathrm{HCO}_{3}{ }^{-}$ions were above the permissible limit set by WHO at Beseka, Melkasedi, Ambash, Meteka hot spring, and Mojo. The concentration of $\mathrm{Cl}^{-}$ion at Melkasedi, Beseka, Akaki, and Wonji is higher and exceeds the permissible limit. The whole result shows that Beseka Lake water has a significant effect on the increment of irrigation water quality parameters amount and aggravates soil salinity to downstream irrigation farms. Generally, the concentration of soluble cations and anions was higher during the dry season in which the flow of the river becomes low and the minimum concentration of these ions was observed during the high flow season in summer.

This study indicates that there is a need to generate continuous information about the irrigation water quality of Awash River in Rift Valley of Ethiopia to be able to manage and control the release of untreated wastewater from industries and discharging of Beseka Lake water into Awash River water. Currently, great attention has to be taken for the prevention and protection of environmental pollution by industrial wastewater at industrial parks constructed around the river.

\section{Data Availability}

The data used to support the findings of this study are available from the corresponding author upon request.

\section{Conflicts of Interest}

The authors declare no conflicts of interest.

\section{Acknowledgments}

The authors acknowledge the Ethiopian Institute of Agricultural Research, Werer Agricultural Research Center, for laboratory and equipment support, sample collection, transportation, and laboratory analysis.

\section{References}

[1] A. Amare, "Corporate environmental responsibility in Ethiopia: a case study of the Akaki river basin," Ecosystem Health and Sustainability, vol. 5, no. 1, pp. 57-66, 2019.

[2] FAO and IHE Delft, Water Accounting in the Awash River Basin, FAO WaPOR Water Accounting Reports, Rome, Italy, 2020.

[3] T. Belay and H. Tizazu, "Assessment of pollution status of soils and vegetables irrigated by Awash river and its selected tributaries," International Journal of Environmental Sciences \& Natural Resources, vol. 18, no. 5, pp. 163-168, 2019.

[4] M. Gedefaw, H. Wang, D. Yan et al., "Water resources allocation systems under irrigation expansion and climate change scenario in Awash river basin of Ethiopia," Water, vol. 11, no. 10, pp. 1966-2015, 2019.

[5] F. Degefu, A. Lakew, Y. Tigabu, and K. Teshome, "The water quality degradation of upper Awash river, Ethiopia," Ethiopian Journal of Environmental Studies and Management, vol. 6, no. 1, pp. 58-66, 2013.

[6] A. S. Keraga, Z. Kiflie, and A. N. Engida, "Evaluating water quality of Awash river using water quality index," International Journal of Water Resources and Environmental Engineering, vol. 9, no. 11, pp. 243-253, 2017.

[7] M. Ayana, G. Tekly, M. Abate, M. Eshetu, and M. Mada, "Irrigation water pricing in Awash river basin of Ethiopia: evaluation of its impact on scheme-level irrigation performances and willingness to pay," African Journal of Agricultural Research, vol. 10, no. 6, pp. 554-565, 2015.

[8] H. A. Shishaye and A. T. Asfaw, "Analysis and evaluation of the spatial and temporal variabilities of river water quality parameters," Applied Water Science, vol. 10, no. 6, pp. 141-20, 2020.

[9] Y. A. Yimer and A. Geberkidan, "The pollution status of Awash river basin (Ethiopia) using descriptive statistical techniques," American Journal of Water Resources, vol. 8, no. 2, pp. 56-68, 2020.

[10] M. Gedefaw, H. Wang, D. Yan et al., "Trend analysis of climatic and hydrological variables in the Awash river basin, Ethiopia," Water, vol. 10, pp. 1-14, 2018.

[11] G. Taddese, K. Sonder, and D. Peden, The Water of the Awash River Basin a Future Challenge to Ethiopia, ILRI, Addis Ababa, Ethiopia, 2015.

[12] A. S. Keraga, Z. Kiflie, and A. N. Engida, "Spatial and temporal water quality dynamics of Awash river using multivariate statistical techniques," African Journal of Environmental Science and Technology, vol. 11, no. 11, pp. 565-577, 2017.

[13] A. C. Medeiros, K. R. F. Faial, K. do Carmo Freitas Faial et al., "Quality index of the surface water of Amazonian rivers in industrial areas in Pará, Brazil," Marine Pollution Bulletin, vol. 123, no. 1-2, pp. 156-164, 2017.

[14] D. Kadyampakeni, R. Appoh, J. Barron, and E. BoakyeAcheampong, "Analysis of water quality of selected irrigation water sources in Northern Ghana," Water Science \& Technology Water Supply, vol. 18, pp. 1-11, 2018.

[15] M. Zaman, S. A. Shahid, and L. Heng, Guideline for Salinity Assessment, Mitigation and Adaptation Using Nuclear and Related Techniques, Springer, Berlin, Germany, 2018.

[16] M. Zaman, S. A. Shahid, and L. Heng, "Irrigation water quality," International Atomic Energy Agency, pp. 113-131, 2018. 
[17] G. Estefan, R. Sommer, and J. Ryan, Methods of Soil, Plant, and Water Analysis: A Manual for the West Asia and North Africa Region, ICARDA, Beirut, Lebanon, 3rd edition, 2013.

[18] Y. K. Kalkhajeh, B. J. Amiri, B. Huang et al., "Methods for sample collection, storage, and analysis of freshwater phosphorus," Water, vol. 11, pp. 1-24, 2019.

[19] O. S. Aboyeji and O. O. Ogunkoya, "Assessment of surface water quality of inland valleys for cropping in SW Nigeria," Applied Water Science, vol. 7, no. 2, pp. 987-996, 2017.

[20] T. A. Bauder, R. M. Waskom, P. L. Sutherland, and J. G. Davis, Irrigation Water Quality Criteria, Colorado State University, Fort Collins, CO, USA, 2011.

[21] M. Ramesh and K. E. Valuthi, "Water quality parameters of ground water samples in Tamilnadu, Kerela and Pondicherry," Pelagia Research Library, vol. 3, no. 5, pp. 1272-1275, 2012.

[22] H. A. Shishaye, "Water quality analysis and evaluation using graphical methods: a case study of Lake Beseka, Ethiopia," Ethiopian Journal of Environmental Studies \& Management, vol. 10, no. 8, pp. 1054-1070, 2017.

[23] Y. D. Ezlit, R. J. Smith, and S. R. Raine, A Review of Salinity and Sodicity in irrigation, Cooperative Research Centre for Irrigation Futures, Brisbane, Australia, 2010.

[24] F. Guy, "Irrigation water quality standards and salinity management strategies," Texax Agricultural Extension Services, pp. 3-18, Texax A\&M University System, College Station, TX, USA, 2003.

[25] G. Hussain, A. Alquwaizan, and A. Al-Zarah, "Guidelines for irrigation water quality and water management in the Kingdom of Saudi Arabia: an overview," Journal of Applied Sciences, vol. 10, no. 2, p. 79, 2010.

[26] H. Jeong, H. Kim, and T. Jang, "Irrigation water quality standards for indirect wastewater reuse in agriculture: a contribution toward sustainable wastewater reuse in South Korea," Water, vol. 8, pp. 1-18, 2016. 